\title{
A cautionary tale: a study of a methane enhancement over the North Sea
}

DOI:

10.1002/2017JD026626

Document Version

Accepted author manuscript

Link to publication record in Manchester Research Explorer

\section{Citation for published version (APA):}

Cain, M., Warwick, N., Fisher, R. E., Lowry, D., Lanoiselle, M., Nisbet, E., France, J., Pitt, J., O'Shea, S., Bower, K., Allen, G., Illingworth, S., Manning, A., Bauguitte, S. J-B., Pisso, I., \& Pyle, J. A. (2017). A cautionary tale: a study of a methane enhancement over the North Sea. Journal of Geophysical Research: Atmospheres. https://doi.org/10.1002/2017JD026626

Published in:

Journal of Geophysical Research: Atmospheres

\section{Citing this paper}

Please note that where the full-text provided on Manchester Research Explorer is the Author Accepted Manuscript or Proof version this may differ from the final Published version. If citing, it is advised that you check and use the publisher's definitive version.

\section{General rights}

Copyright and moral rights for the publications made accessible in the Research Explorer are retained by the authors and/or other copyright owners and it is a condition of accessing publications that users recognise and abide by the legal requirements associated with these rights.

\section{Takedown policy}

If you believe that this document breaches copyright please refer to the University of Manchester's Takedown Procedures [http://man.ac.uk/04Y6Bo] or contact uml.scholarlycommunications@manchester.ac.uk providing relevant details, so we can investigate your claim.

\section{OPEN ACCESS}




\section{A cautionary tale: a study of a methane enhancement over the North Sea}

M. Cain ${ }^{1}$, N. J. Warwick ${ }^{1,2}$, R. E. Fisher ${ }^{3}$, D. Lowry ${ }^{3}$, M. Lanoisellé ${ }^{3}$, E. G.

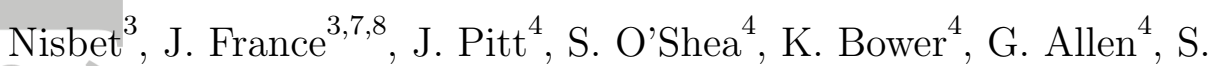

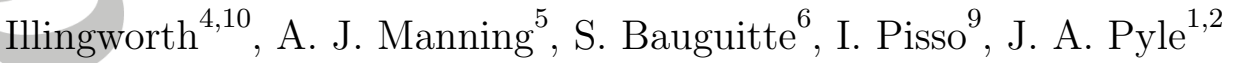

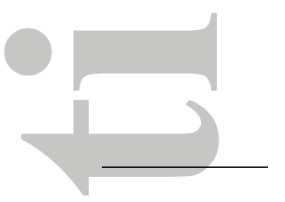

Michelle Cain, michelle.cain@atm.ch.cam.ac.uk

${ }^{1}$ Centre for Atmospheric Science,

University of Cambridge, Cambridge, CB2

1EW, UK

${ }^{2}$ National Centre for Atmospheric Science,

UK

${ }^{3}$ Department of Earth Sciences, Royal

Holloway, University of London, Egham,

TW20 0EX, UK

${ }^{4}$ School of Earth, Atmospheric and

Environmental Sciences, University of

Manchester, Oxford Road, Manchester, M13

9PL, UK

This article has been accepted for publication and undergone full peer review but has not been through the copyediting, typesetting, pagination and proofreading process, which may lead to differences between this version and the Version of Record. Please cite this article as doi: 10.1002/2017JD026626

(C)2017 American Geophysical Union. All Rights Reserved. 


\section{Abstract.}

${ }^{5}$ UK Meteorological Office, Fitzroy Rd,

Exeter, UK

${ }^{6}$ Facility for Airborne Atmospheric

Measurements (FAAM), Building 125,

Cranfield University, Cranfield, Bedford,

MK43 0AL, UK

${ }^{7}$ School of Environmental Sciences,

University of East Anglia, Norwich, NR4

7TJ, UK

${ }^{8}$ British Antarctic Survey, High Cross,

Madingley Road, Cambridge, CB3 0ET, UK

${ }^{9}$ NILU - Norwegian Institute for Air

Research, Dept. Atmospheric and Climate

Research, Instituttveien 18, 2007 Kjeller,

Norway

${ }^{10}$ School of Research, Enterprise and

Innovation, Manchester Metropolitan

University, Chester Street, Manchester, M1

$5 \mathrm{GD}, \mathrm{UK}$

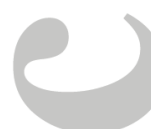

(C)2017 American Geophysical Union. All Rights Reserved. 
Airborne measurements of a methane $\left(\mathrm{CH}_{4}\right)$ plume over the North Sea from August 2013 are analyzed. The plume was only observed downwind of circumnavigated gas fields, and three methods are used to determine its source.

First, a mass balance calculation assuming a gas field source gives a $\mathrm{CH}_{4}$ emission rate between $2.5 \pm 0.8 \times 10^{4}$ and $4.6 \pm 1.5 \times 10^{4} \mathrm{~kg} \mathrm{~h}^{-1}$. This would be greater than the industry target of a $0.5 \%$ leak rate if it were emitting for more than half the time. Second, annual average $\mathrm{UK} \mathrm{CH}_{4}$ emissions are combined with an atmospheric dispersion model to create pseudo-observations. Clean air from the North Atlantic passed over mainland UK, picking up anthropogenic emissions. To best explain the observed plume using pseudo-observations, an additional North Sea source from the gas rigs area is added. Third, the $\delta^{13} \mathrm{C}-\mathrm{CH}_{4}$ from the plume is shown to be $-53 \%$, which is lighter than fossil gas but heavier than the UK average emission. We conclude that either an additional small-area mainland source is needed, combined with temporal variability in emission or transport in small-scale meteorological features. Alternatively, a combination of additional sources that are at least $75 \%$ from the mainland $(-58 \%)$ and up to $25 \%$ from the North Sea gas rigs area $(-32 \%)$ would explain the measurements. Had the isotopic analysis not been performed, the likely conclusion would have been of a gas field source of $\mathrm{CH}_{4}$. This demonstrates the limitation of analysing mole fractions alone, as the simplest explanation is rejected based on analysis of isotopic data.

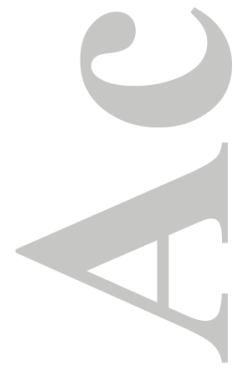

(C)2017 American Geophysical Union. All Rights Reserved. 


\section{Keypoints:}

- Three methods are used to analyze a methane plume observed over the

North Sea

- Only with use of all three methods can the source of the plume be un-

derstood

- Measurement of carbon isotopes is essential for source identification, given

limitations to the model and the extent of the measurements
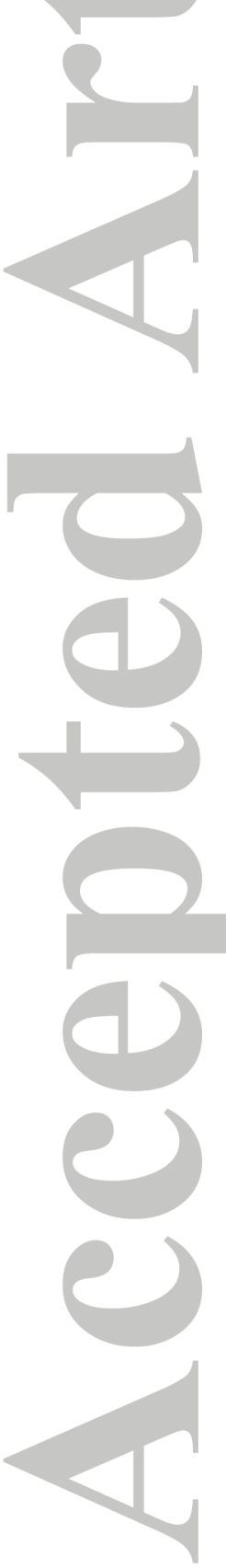

(C)2017 American Geophysical Union. All Rights Reserved. 


\section{Introduction}

Reduction of methane $\left(\mathrm{CH}_{4}\right)$ emissions is potentially an effective way of reducing the radiative forcing from greenhouse gases in the short term. The atmospheric lifetime of $\mathrm{CH}_{4}$ is about 10 years, much shorter than that for carbon dioxide $\left(\mathrm{CO}_{2}\right)$, so reducing its emissions would rapidly reduce its atmospheric abundance. As $\mathrm{CH}_{4}$ is the second most important well-mixed greenhouse gas after $\mathrm{CO}_{2}$, this would have a strong impact on radiative forcing. The Intergovernmental Panel on Climate Change's most recent report states that methane's global warming potential is 84 times that of $\mathrm{CO}_{2}$ over 20 years, and 28 times over 100 years [Myhre et al., 2013]. More recent work by Etminan et al. [2016] suggests it is $25 \%$ higher than this when shortwave forcing is included.

If effective measures are to be taken to reduce $\mathrm{CH}_{4}$ emissions, a good understanding of its present sources is first needed. However, the global atmospheric budget of $\mathrm{CH}_{4}$ is complex and incompletely understood. The dominant sink is by oxidation, mainly by reaction with $\mathrm{OH}$, and the balance between different sources is uncertain. A comprehensive review of the literature by Saunois et al. [2016] reports estimated global emissions to the atmosphere over the decade 2003 to 2012 from top-down inversion studies and from bottom-up inventories. They found that top-down methods gave lower total emissions (558 $\mathrm{Tg} \mathrm{CH}_{4}$

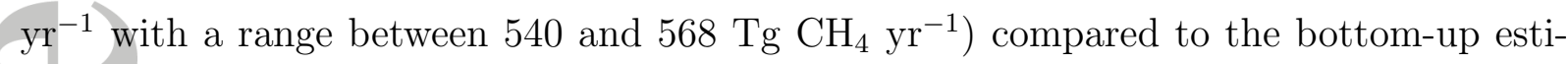
mates (736 $\mathrm{Tg} \mathrm{CH}_{4} \mathrm{yr}^{-1}$ with a range between 596 and $884 \mathrm{Tg} \mathrm{CH}_{4} \mathrm{yr}^{-1}$ ). Approximately $40 \%$ of emissions are from natural sources and $60 \%$ are anthropogenic. Wetlands, in the tropics and high northern latitudes, are one major source, with estimates ranging between 127 to 202 (top-down) and 153 to 227 (bottom-up) $\mathrm{Tg} \mathrm{CH}_{4} \mathrm{yr}^{-1}$. Agriculture and waste,

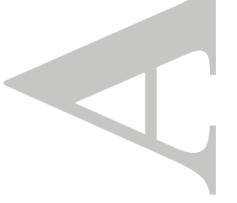

(C)2017 American Geophysical Union. All Rights Reserved. 
including cattle farming, paddy fields and landfill, contribute 115 to 243 (top-down) and 178 to 206 (bottom-up) $\mathrm{Tg}_{\mathrm{CH}_{4}} \mathrm{yr}^{-1}$. Fossil fuel emissions are a slightly smaller source,

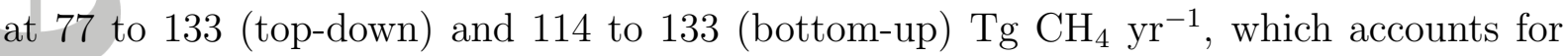
$15-18 \%$ and $14-24 \%$ of the total emissions respectively.

In contrast to the literature reviewed in Saunois et al. [2016], a recent study by Schwietzke et al. [2016] found that fossil fuel emissions were 60 to $100 \%$ higher than in the existing literature, at about $195 \mathrm{Tg} \mathrm{CH}_{4} \mathrm{yr}^{-1}$ (combining fossil fuel industrial emissions and natural geological seepage). They attributed $\mathrm{CH}_{4}$ from different sources by combining the newest and most comprehensive isotopic database with an atmospheric box model. The ratio of carbon isotopes in $\mathrm{CH}_{4}\left({ }^{13} \mathrm{C}:{ }^{12} \mathrm{C}\right)$ relative to a standard is known as $\delta^{13} \mathrm{C}-\mathrm{CH}_{4}$, and is used to identify different sources of $\mathrm{CH}_{4}$, as each source emits at a different ratio. The findings in Schwietzke et al. [2016] signal a greater potential for reductions in fossil fuel emissions than previously thought. To reduce uncertainty in our emissions estimates, more measurements and modeling of $\mathrm{CH}_{4}$ and its isotopes are needed.

The Climate Change Act in the UK has a legal target to reduce greenhouse gas emissions by $80 \%$ compared to 1990 levels by 2050 (and by $34 \%$ by 2020). Because of its relatively short lifetime, reduction in $\mathrm{CH}_{4}$ emissions could be a particularly effective measure, especially during a transitional phase. However, national $\mathrm{CH}_{4}$ emissions by sector need to be clearly known in order to determine the most effective policy.

In the UK, greenhouse gas emissions are calculated annually in the National Atmospheric Emissions Inventory (NAEI, http://www.naei.org.uk), and reported to the United Nations Framework Convention on Climate Change (UNFCCC). Emissions factors are assigned for each different source type, with sources falling under wider categories including (C)2017 American Geophysical Union. All Rights Reserved. 
agriculture, energy supply, industrial processes and waste management. Combining these with maps of source location builds the emission inventory from the bottom-up. Total $\mathrm{CH}_{4}$ emissions from the UK in 2013 are reported as $56 \mathrm{Tg} \mathrm{CO}_{2} \mathrm{e}$, equivalent to $2.2 \mathrm{Tg}$ $\mathrm{CH}_{4}$ (UK Greenhouse Gas Inventory 1990 to 2014: Annual Report for submission under the Framework Convention on Climate Change, 2016).

UK emissions are also estimated independently from the top-down using an inverse model-based approach and atmospheric $\mathrm{CH}_{4}$ measurements. For example, Manning et al. [2011] used an inversion procedure using the NAME (Numerical Atmospheric-dispersion Modeling Environment) air-parcel dispersion model to estimate emissions of $\mathrm{CH}_{4}$ since 1990. Their derived values showed good agreement with the NAEI in the 2000s (the NAEI emissions are within the 25th to 75 th percentile of the inversion results for every year simulated), but poor agreement during the 1990s (where the NAEI emissions were larger than the inversion's 95th percentile for most years, by over a factor of 2 for some years). Since its publication, the bottom-up estimates in the NAEI have been revised upwards, taking them further from the top-down approach, with agreement being reached only by the late 2000s. Polson et al. [2011] also evaluated the NAEI greenhouse gas emissions, using an inversion based on aircraft data from flights circumnavigating the UK in 2005/6 and the NAME model. For $\mathrm{CH}_{4}$, the mean inversion estimate of UK emissions $(3.5 \mathrm{Tg}$

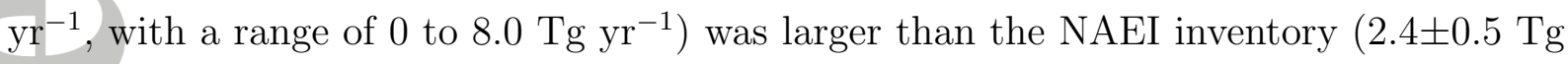
$\mathrm{yr}^{-1}$ for 2005), although the uncertainty range was very large and entirely encompassed the NAEI estimate.

The energy sector accounts for about a third of all greenhouse gas emissions in the UK (95\% is emitted as $\mathrm{CO}_{2}$ ), including a number of offshore gas fields in the seas around (C)2017 American Geophysical Union. All Rights Reserved. 
Britain. In December 2015, the government awarded 93 new licences to explore oil and gas on the UK mainland, three quarters of which relate to the hydraulic fracturing of shale (https://www.gov.uk/guidance/oil-and-gas-licensing-rounds\#th-landwardlicensing-round).

Atmospheric $\mathrm{CH}_{4}$ concentrations have been growing since the industrial revolution, however the rate of growth varies significantly from year to year. The growth rate was large in the 1980s and slowed in the 1990s. Several factors have been proposed to explain this, although there is no consensus in the literature. Possible explanations include a decrease in fossil fuel extraction and efficiency improvements in the former Soviet Union [Dlugokencky, 2003; Schaefer et al., 2016]; a combination of reduced northern anthropogenic emissions and reduced wetland emissions [Bousquet et al., 2006]; an increased amount of OH, which reduces the $\mathrm{CH}_{4}$ lifetime and therefore abundance [Fiore et al., 2006; McNorton et al., 2016; Schaefer et al., 2016].

It is also not certain what has caused more recent increases to the global atmospheric growth rate. Between 1999 and 2006, the global $\mathrm{CH}_{4}$ burden was stable. Since 2007, it has been increasing again, growing at about 6 ppb per year [Nisbet et al., 2016]. Bergamaschi et al. [2013] attribute this trend mainly to anthropogenic emissions from the tropics and northern mid-latitudes, with interannual variability of wetlands and biomass burning superimposed. However, Schaefer et al. [2016] show that source increases since 2006 appear to be predominantly biogenic and propose tropical agriculture as the likely reason. Nisbet et al. [2016] concur that the recent increases are biogenic, but conclude that tropical wetlands are more consistent with the observed interannual variability. Recent work by

Turner et al. [2016] based on satellite and surface measurements revealed a $30 \%$ increase (C)2017 American Geophysical Union. All Rights Reserved. 
in $\mathrm{CH}_{4}$ emissions from the USA in the last decade, however further work is needed to identify specific sources. The $\mathrm{OH}$ sink is another candidate driver for global trends. Both Rigby et al. [2017] and Turner et al. [2017] demonstrate that variations in $\mathrm{OH}$ can explain the recent upward trend without the need to invoke sudden changes in $\mathrm{CH}_{4}$ sources.

Top-down methods are used to calculate emissions independently of bottom-up inventories. Karion et al. [2013] have estimated emissions from an oil and gas field in Utah.

They made aircraft measurements of $\mathrm{CH}_{4}$ while circumscribing the field and employed a mass balance approach to derive emissions. On one particular day their derived emissions corresponded to around $6-11 \%$ of the average hourly natural gas production from the field. This is a large value, and it is clearly important to establish how large and how variable are emissions from natural gas fields. The same approach was used in Karion et al. [2015] to estimate $\mathrm{CH}_{4}$ emissions from the Barnett Shale region in Texas. Their calculated value of $60 \pm 11 \times 10^{3} \mathrm{~kg} \mathrm{hr}^{-1}$, or $16.7 \pm 3.1 \mathrm{~kg} \mathrm{~s}^{-1}$, was three times higher than the total natural gas and petroleum associated emissions reported by industry to the US Environmental Protection Agency's Greenhouse Gas Reporting Program in the same region, and five

times higher than the oil and gas sector emissions in the Emission Database for Global Atmospheric Research (EDGAR) $\mathrm{CH}_{4}$ inventory. Aircraft measurements were also used by Conley et al. [2016] to estimate emissions from the Aliso Canyon leak in 2015, showing that at its peak, it was releasing as much $\mathrm{CH}_{4}$ as the rest of the entire Los Angeles basin. The total UK gas production from offshore gas and oil fields between November 2014 and October 2015 was approximately 36 Tg (https://itportal.decc.gov.uk/pprs/report3.pdf, accessed January 2016), so that a $1 \%$ leak rate (commonly referred to as fugitive emission) would be equivalent to nearly a fifth of the annual UK emissions of $\mathrm{CH}_{4}$. Leaks of this

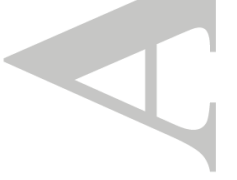

(C)2017 American Geophysical Union. All Rights Reserved. 
magnitude, which as a percentage are lower than reported in, for example, Karion et al. [2013] and Karion et al. [2015], could therefore be a potentially important contributor to UK emissions.

Methane in the Arctic: Measurements, process studies and Modeling (MAMM) is a project aimed at studying Arctic $\mathrm{CH}_{4}$ using ground and airborne measurements interpreted by a variety of numerical models. Four one-week aircraft campaigns took place in the summers of 2012, 2013 and 2014. The UK BAe-146-301 Atmospheric Research Aircraft operated out of Kiruna Airport in northern Sweden, making measurements over the Scandinavian wetlands and as far north as Svalbard (see Section 2 for details). On each occasion the opportunity was taken on transit back to the UK to make measurements over gas and oil fields in the North Sea. During one flight in particular, meteorological conditions were suitable for the estimation of emissions using a mass balance approach. Here, we use several methods to identify $\mathrm{CH}_{4}$ emissions based on the aircraft observations (mass balance, air mass history modeling and carbon isotope analysis). The aim is to provide an estimate of emissions on one particular day and, importantly, to evaluate whether these methods are fit for purpose, and to identify what measurements must be collected to use them successfully.

\section{Measurements}

Measurements were taken on board the UK's Facility for Airborne Atmospheric Measurements (FAAM) BAe-146-301 Atmospheric Research Aircraft, subsequently referred to as the aircraft.

Measurements of $\mathrm{CH}_{4}$ mole fraction were made on board the aircraft using a Fast Greenhouse Gas Analyzer (FGGA; Los Gatos Research Inc., USA). Full details of the (C)2017 American Geophysical Union. All Rights Reserved. 
measurement principle employed (off-axis integrated cavity output spectroscopy) are given by Paul et al. [2001], and details regarding the implementation of the instrument on board the aircraft, including an assessment of the instrument performance over several campaigns, are presented by O'Shea et al. [2013]. The instrument was calibrated in flight using standards traceable to the WMO greenhouse gas scale [Dlugokencky, 2005]. A target standard was used to assess instrument drift between calibrations; O'Shea et al. [2013] report a mean offset from the WMO-traceable cylinder composition of -0.07 ppb for $\mathrm{CH}_{4}$, with a standard deviation of $2.5 \mathrm{ppb}$ for the $1 \mathrm{~Hz}$ measurements. They also report uncertainties of $1.0 \mathrm{ppb}$ and $0.8 \mathrm{ppb}$ corresponding to the correction for the influence of water vapor on the measurements, and the certification of the target cylinder on the WMO scale respectively. The uncertainty on an individual $1 \mathrm{~Hz}$ measurement can then be calculated by combining these uncertainties with the standard deviation of $1 \mathrm{~Hz}$ target measurements, giving a total uncertainty of $2.8 \mathrm{ppb}$ on each individual measurement. $\mathrm{CO}_{2}$ measurements were also made using the FGGA, with a total uncertainty of 0.68 ppm on each $1 \mathrm{~Hz}$ measurement, and are used in this study to aid $\mathrm{CH}_{4}$ source identification.

Separate measurements of $\mathrm{CH}_{4}$ and $\mathrm{CO}_{2}$ were made by analysing whole-air-samples (WAS). WAS were collected in stainless steel flasks (for a description, see Lewis et al. [2013]) and analyzed post-flight at Royal Holloway University of London using cavity-ring down spectroscopy (CRDS, Model G1301, Picarro Inc, USA). Uncertainty is estimated at $\pm 0.5 \mathrm{ppb}$ and $\pm 0.1 \mathrm{ppm}$ for $\mathrm{CH}_{4}$ and $\mathrm{CO}_{2}$, respectively. During the MAMM project the mean bias of the 400 WAS relative to the in situ measurements was $-0.5( \pm 4.6$ at $1 \sigma)$ ppb for $\mathrm{CH}_{4}$ and $-0.16( \pm 0.46$ at $1 \sigma)$ ppm for $\mathrm{CO}_{2}$ [O'Shea et al., 2014]. Additional air samples were collected in Tedlar bags when narrow plumes were encountered. The advantage of 
the bags was that they could be filled in 5 seconds compared with 20 seconds for the flasks, allowing short lived plumes to be sampled with less dilution. $\mathrm{CH}_{4}$ mole fraction was analyzed in the bags post-flight also by CRDS. All the flask and bag samples were analyzed for $\delta^{13} \mathrm{C}$ isotopic ratios of $\mathrm{CH}_{4}$, using continuous-flow gas chromatography/isotope-ratio mass spectrometry (CF-GC-IRMS), with a mean repeatability of $0.05 \%$ [Fisher et al., 2006]. Samples were measured in triplicate with an additional measurement analysis if the first 3 were not within $0.1 \%$.

On board measurements of many atmospheric parameters were taken, including pressure, temperature and the 3D wind vector with an estimated uncertainty of $0.3 \mathrm{hPa}, 0.1$ $\mathrm{K}$ and $0.2 \mathrm{~ms}^{-1}$, respectively [Allen et al., 2011]. Measurements of carbon monoxide (CO) and water vapor are used here to identify boundary layer air masses. Mole fractions of CO were measured using VUV (vacuum ultraviolet) fast-fluorescence spectrometry, with an uncertainty of 2\% (AL5002, Aerolaser GmbH, Germany; Gerbig et al. [1999]).

\section{Dispersion Modeling}

To study the air mass histories of the sampled air, the Lagrangian particle dispersion model NAME [Jones et al., 2007] is run backwards from the location of the aircraft flight track. Further detail about the flight is in Section 4.1. The full flight track is shown in the supporting information, Figure S1. The model is run using the UK Met Office's Unified Model meteorological analyses [Cullen, 1993], at a resolution of approximately 25 $\mathrm{km}\left(0.3516^{\circ} \times 0.2344^{\circ}\right)$. Theoretical inert model air parcels, each representing a small amount of $\mathrm{CH}_{4}$, move according to the modeled 3D wind fields, with a random walk superimposed to represent turbulent motions unresolved by the meteorological fields.

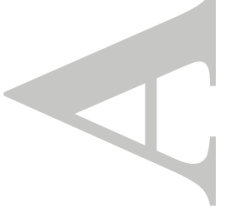

(C)2017 American Geophysical Union. All Rights Reserved. 
Air parcels can be released either forwards or backwards in time. By running the model backwards in time, it is possible to calculate air mass histories, showing locations where the parcels spend time in the model's planetary boundary layer (PBL). These can be combined with emission maps to determine how measurement locations are affected by sources [France et al., 2016].

Here, we run the NAME model backwards in time, with air parcels released from the flight track a rate of 200,000 per hour. When the air parcels pass through the modeled boundary layer during the 24 hours prior to the flight, they contribute to the boundary layer footprint. The footprint is defined as the time-integrated air concentration within the boundary layer. Footprint maps were calculated to represent every 5 minutes along the flight track, an example of which is shown in Figure 4. During the box pattern (shown in Figure 1), the aircraft moves about $33 \mathrm{~km}$ in 5 minutes. The NAME footprints were calculated using a $0.1^{\circ} \mathrm{x} 0.1^{\circ}$ grid over the area $10^{\circ} \mathrm{W}$ to $4^{\circ} \mathrm{E}$ and $50^{\circ} \mathrm{N}$ to $60^{\circ} \mathrm{N}$.

The footprint map and the annual average NAEI emissions are used to calculate the $\mathrm{CH}_{4}$ mole fraction enhancement at our measurement points along the flight track. The footprint is divided by the total mass of air parcels, and multiplied by the grid cell area to work out the dilution matrix. This method is discussed in, for example, Ashfold et al. [2014]. The enhancement above the background along the flight track is the product of the dilution matrix and the gridded emissions in the footprint area. The calculated values of $\mathrm{CH}_{4}$ are called pseudo-observations. They represent the increment above some background due to the emissions transported by the modeled winds. The background $\mathrm{CH}_{4}$ is taken to be $1865 \mathrm{ppb}$, based on the AGAGE [Prinn et al., 2000] $\mathrm{CH}_{4}$ measurements from $\sim 12$ UTC on 18 August 2013 at Mace Head on the west coast of the Irish Republic (C)2017 American Geophysical Union. All Rights Reserved. 
(location marked on Figure S1). This is chosen as the back trajectories passed over the region at approximately this time.

\section{Results}

\subsection{Overview}

As part of the MAMM project, three flights took place over the North Sea with the aim of sampling downwind of gas and oil rigs in the Leman field, in 2012 and 2013. The Leman gas field is one of the largest point sources in the NAEI inventory, with a total of $1.7 \times 10^{6} \mathrm{~kg}$ emitted in 2014 through venting from two points in the inventory. Leman first produced gas in the late $1960 \mathrm{~s}$, and is situated between approximately $53^{\circ} 0^{\prime} \mathrm{N}$ to $53^{\circ} 10^{\prime} \mathrm{N}$ and $2^{\circ} 0^{\prime} \mathrm{E}$ to $2^{\circ} 24 ' \mathrm{E}$ (https://www.ogauthority.co.uk/data-centre/interactive-maps-andtools/). There are a total of 33 platforms in the Leman field. Gas from these platforms and from other nearby North Sea fields is processed at the main platform, Leman Alpha. Situated immediately to the north west of the Leman field is the smaller Vulcan gas field with two platforms. Maps of the fields can be found at https://www.gov.uk/guidance/oiland-gas-offshore-maps-and-gis-shapefiles.

Data from flight B809 on 23 September 2013 showed an elevation in $\mathrm{CH}_{4}$ mole fraction of predominantly biogenic origin coming from the UK when approaching the coast, and transient and high enhancements of thermogenic $\mathrm{CH}_{4}\left(\delta^{13} \mathrm{C}_{-} \mathrm{CH}_{4}-33.0 \pm 1.0 \%\right)$ from individual rigs as they were passed downwind (see Figure S2). There was an extremely low and variable mean wind speed on this day, therefore a conventional mass balance calculation was not possible as this relies on a stable and consistent flow regime. However light winds allowed isotopic signatures from the gas and oil rigs to be clearly identified, as a comparison point to other flights.

(C)2017 American Geophysical Union. All Rights Reserved. 
The flight we focus on in the following analysis, B802 from Aberdeen to Cranfield, targeted the Leman gas fields on 19 August 2013. The surface pressure during the flight is shown in Figure S3, based on the ERA-Interim reanalysis [Dee et al., 2011]. A slow moving high-pressure system was present to the southwest of the United Kingdom, with outflow from the Humberside region being advected into the target area of the flight. The grey shading in Figure S3 marks the approximate area where the research flight flew low over the sea, which includes the Leman and Vulcan gas fields.

The initial flight segment from Aberdeen was at high altitude, followed by a descent to waypoint $\mathrm{A}$ at $53.1^{\circ} \mathrm{N}, 3.0^{\circ} \mathrm{E}$ (all waypoints are marked in Figure 1), which is close to the Leman gas field (approximate location shown by the maroon box in Figure 1). The temperature, total water content, ozone, carbon monoxide and $\mathrm{CH}_{4}$ measurements on descent to the sea surface at point $\mathrm{A}$ and the ascent to about $700 \mathrm{~m}$ following the end of the box pattern at point K, are shown in Figure 2. There is about $100 \mathrm{~km}$ and 1 hour 45 minutes between the two profiles, with higher temperatures and water content in the ascent. This is likely to be due to solar heating and near-surface evaporation generating water vapour on a faster timescale than the mixing is occurring.

There is a strong temperature inversion at $2000 \mathrm{~m}$. Below this, there are several less distinct layers, which can be seen by changes in humidity, temperature and trace gases at approximately $1650 \mathrm{~m}, 1300 \mathrm{~m}$ and $500 \mathrm{~m}$. The layer up to $500 \mathrm{~m}$ is relatively well mixed, as the potential temperature (black crosses) remains relatively constant, as does the $\mathrm{CO}$ (black circles). The $\mathrm{CH}_{4}$ has some variability up to $500 \mathrm{~m}$ (about $30 \mathrm{ppb}$ or less than a $2 \%$ range on each profile), suggesting that although recently emitted $\mathrm{CH}_{4}$ has been mixed through the $500 \mathrm{~m}$ layer, it has not yet become mixed to a uniform (C)2017 American Geophysical Union. All Rights Reserved. 
mole fraction throughout. At $500 \mathrm{~m}$ there is a temperature inversion, and the potential temperature increases with height above this inversion, indicating that this is a statically stable layer. This suggests that the well-mixed layer would not easily grow in depth, without additional heating. There is a higher water content in the ascent from point $\mathrm{K}$ compared to the descent to point A, which is likely to be due to near-surface evaporation generating water vapour on a faster timescale than the mixing is occurring.

Soundings from Nottingham, upwind of the flight and marked in Figure S1, from 00:00 and 12:00 UTC on 19 September were sourced from the University of Wyoming Department of Atmospheric Science database (shown in Figure S4). The temperature profile at 00:00 UTC is similar to the aircraft profiles, but at a cooler temperature, with inversions at $200 \mathrm{~m}$ and $1500 \mathrm{~m}$. This is consistent with a more shallow (200 m) nocturnal surface layer over land and a growth in PBL depth to $500 \mathrm{~m}$ because of solar heating during the day. The $1500 \mathrm{~m}$ altitude temperature inversion could be expected to be a residual boundary layer of the previous day's PBL, which corresponds to the layer capped at 2000 $\mathrm{m}$ seen downwind in the aircraft profile offshore.

The 12:00 UTC sounding at Nottingham does not show this stability layer, consistent with a change in the prevailing meteorology (decreasing pressure) and greater PBL ventilation over the course of the day onshore. However this change was not observed at the time and location of the case study downwind. In summary, the soundings are consistent with the aircraft sampling a residual PBL representative of upwind land sources.

The descent to point A reached $15 \mathrm{~m}$ above sea level (asl), based on the on-board radar altimeter. Figure 1 shows the subsequent box pattern sequence of flight legs as the aircraft circuited the Leman field at approximately $80 \mathrm{~m}$ asl. The flight tracks were

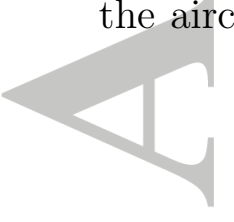

(C)2017 American Geophysical Union. All Rights Reserved. 
designed to cover both upwind and downwind of the gas rigs in the Leman field. The mean wind speed during the crosswind transects was $5.4 \mathrm{~m} \mathrm{~s}^{-1}$ from a bearing of $330^{\circ}$, with a standard deviation of $0.8 \mathrm{~m} \mathrm{~s}^{-1}$ and $5^{\circ}$. Wind barbs at regular intervals along the flight are shown in Figure 1.

Figure 1 also shows the continuous $\mathrm{CH}_{4}$ measurements from the FGGA plotted using a color scale. The most northerly of the approximately east-west flight legs (IJ) was characterised by $\mathrm{CH}_{4}$ mixing ratios between about 1900 to $1930 \mathrm{ppb}$, assumed to be North Sea background levels. More southerly legs showed much higher $\mathrm{CH}_{4}$ mixing ratios, especially towards the east, with elevated $\mathrm{CH}_{4}$ up to 100 ppb above this background, in a plume about $90 \mathrm{~km}$ at its widest. This is referred to in the text as the plume. Some further elevated measurements of $\mathrm{CH}_{4}$ (¿2050 ppb) were also reported, seen more clearly in Figure 3 below. These were of very short duration and always coincident with close proximity to individual rigs. These are referred to as spikes with local influence.

At first sight, the data suggest a source of $\mathrm{CH}_{4}$ in the Leman target area, south of the IJ line, that advected southeastward, spreading horizontally in the northwesterly flow. Had the source been further upwind (e.g. from the land) higher concentrations along the IJ line might have been expected. This hypothesis is tested using the following analyses.

\subsection{Mass Balance Estimate}

Mass balance models have been used to estimate emissions when there is a consistently strong wind blowing in a uniform direction over the source of interest. For example, from an oil and gas field in Karion et al. [2013], and over $\mathrm{CH}_{4}$ emitting wetlands in O'Shea et al. [2014].

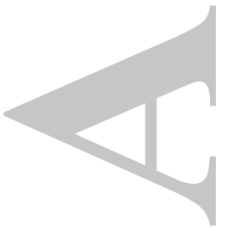

(C)2017 American Geophysical Union. All Rights Reserved. 
On 19 August, the wind speed and direction measured by the aircraft remained relatively constant between waypoints $\mathrm{A}$ and $\mathrm{K}\left(5.4 \mathrm{~m} \mathrm{~s}^{-1}\right.$, standard deviation $0.8 \mathrm{~m} \mathrm{~s}^{-1}$ over transects $\mathrm{AB}, \mathrm{CD}, \mathrm{EF}, \mathrm{GH}$ and IJ). The transit time from the upwind and the furthest downwind leg is 1.85 hours. There is 1.7 hours between points A and K, so the average wind during $\mathrm{A}$ to $\mathrm{K}$ is representative of the wind during its transit over the area. As discussed in the previous section, the vertical profiles suggest that the mixed layer up to $500 \mathrm{~m}$ was not changing rapidly, although there is some change between the initial descent and final ascent.

We can make a mass balance estimate of the $\mathrm{CH}_{4}$ emission source with the following assumptions: that the lowest layer was well mixed on the timescale of horizontal transport over the source region between upwind and downwind sampling (discussed next); that there was no significant transport into or entrainment from the free troposphere (which is consistent with the vertical temperature profile); and that a constant emission flux from the surface is being advected through our target area (which is likely to be a simplification of the real situation, and should be kept in mind when considering the resulting flux).

The simplifying assumption of a well-mixed layer is required to perform the mass balance calculation. We did not profile vertically through the $\mathrm{CH}_{4}$ plume, so there is no data to show whether the $\mathrm{CH}_{4}$ plume was uniform up to $500 \mathrm{~m}$. Figure 2 shows that there is a sharp discontinuity in mixing ratios and a capping temperature inversion at $500 \mathrm{~m}$ when the aircraft profiled near to the target area. Therefore, we assume that the $\mathrm{CH}_{4}$ detected during the box flights at $80 \mathrm{~m}$ asl had been confined in a shallow mixed layer of $500 \mathrm{~m}$ depth. The calculated emission rate will scale linearly with assumed mixed layer height.

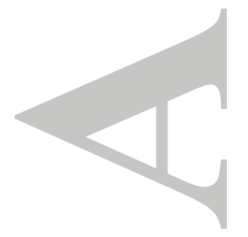

(C)2017 American Geophysical Union. All Rights Reserved. 
Figure 2d shows $\mathrm{CH}_{4}$ during descent to point $\mathrm{A}$ and ascent from point $\mathrm{K}$, with some variability up to $500 \mathrm{~m}$.

To calculate the $\mathrm{CH}_{4}$ emission rate, we use

$$
\text { Emission rate }=\bar{U} \int_{-b}^{b} \Delta S\left(\int_{z_{0}}^{z_{p b l}} n d z\right) \cos \theta d x
$$

where $\bar{U}$ is the mean horizontal wind speed, and $\theta$ is the angle between the wind direction and the line perpendicular to the aircraft transect, such that $\bar{U} \cos \theta$ is the component of the wind vector perpendicular to the flight transect. $\Delta S$ is the $\mathrm{CH}_{4}$ enhancement over the background, which is integrated over the width of the plume (-b to b). The molar density of air, $n$, is integrated over the depth of the boundary layer $\left(z_{0}\right.$ to $\left.z_{p b l}\right)$. Equation 1 gives the amount of $\mathrm{CH}_{4}$ (in moles) emitted from the surface per unit time, assuming no net flux through the PBL top or through the sides of the modeled box. This is illustrated in the schematic in Figure S5.

The mixing ratio enhancement in the plume above background $(\Delta S)$, and the width of the plume (distance between -b and b), can both be estimated from the aircraft data. We consider three approximately east-west flight legs, AB, EF and GH, which are shown in Figure 3, as being transects of the plume. The background is defined by the mean $\mathrm{CH}_{4}$ along the IJ leg to be $1913 \mathrm{ppb}$, with a standard deviation of $11 \mathrm{ppb}$. The plume edges have been defined as the points closest to the background value along each transect, and are defined in Table 1 by the start and end times in decimal hours.

One point to consider is that we did not sample the complete plume, because of restrictions on where we had permission to fly. Figures 1 and 3 show that the plume probably extended further east than the flight track. If this was the case and we had sampled fur-

(C)2017 American Geophysical Union. All Rights Reserved. 
ther east, we would have calculated a larger total emission. We have estimated this larger extent by performing the emission calculation while assuming the plume is symmetrical for transects $\mathrm{AB}, \mathrm{EF}$ and GH. Here, the western half of the plume is defined from the peak to the widest extent to the west. It is assumed that had we sampled fully, the plume would be symmetrical on the eastern side of the peak. Rows in Table 1 labelled "west half doubled" show these values. Note that the times denote the time from western extent to the peak, but the width denotes that distance doubled.

Table 1 shows the range of calculated emissions from each of the downwind flight legs $\mathrm{AB}, \mathrm{EF}$ and $\mathrm{GH}$, ranging from $2.5 \pm 0.8 \times 10^{4}$ to $4.6 \pm 1.5 \times 10^{4} \mathrm{~kg} \mathrm{hr}^{-1}(1.6 \pm 0.5 \mathrm{x}$ $10^{6}$ to $\left.2.8 \pm 0.9 \times 10^{6} \mathrm{~mol} \mathrm{hr}{ }^{-1}\right)$. The uncertainties have been estimated for each term in the emission calculation, and propagated to calculate an uncertainty on the emission, as shown in Table 1, with details in the supporting material.

To calculate a flux (emission per unit area), an area over which the $\mathrm{CH}_{4}$ is released must be assumed. Here, we assume this to be the whole area between the upwind flight leg IJ and the relevant downwind leg, assuming the width of the emission area is uniform and equal to the width of the plume as defined in the calculation. This will provide an average flux per unit area. Based on the different plume definitions in table 1, the mean emission flux per unit area ranges between approximately 1.8 to $5.8 \times 10^{-9} \mathrm{~kg} \mathrm{~m}^{-2} \mathrm{~s}^{-1}$. The annual mean UK emissions in 2012 (which are used in the calculations in Section 4.3) correspond to a flux of about $9 \times 10^{-11} \mathrm{~kg} \mathrm{~m}^{-2} \mathrm{~s}^{-1}$ (calculated by averaging all nonzero elements of the NAEI $\mathrm{CH}_{4}$ emissions inventory), so that our value, which we assume is related to a relatively short, localised emissions pulse is an order of magnitude higher than the UK annual average.

(C)2017 American Geophysical Union. All Rights Reserved. 
Karion et al. [2013] estimate the emissions from a natural gas and oil field in Utah to be $5.5 \pm 1.5 \times 10^{4} \mathrm{~kg} \mathrm{hr}^{-1}$, which they equate to a leakage from natural gas from the same fields of between 6 and $12 \%$. They point out that such losses would be an important offset of the short-term climate benefit accruing from the use of natural gas (as well as a significant economic loss). Our estimated emission rates of the same order of magnitude as those found by Karion et al. [2013]. According to the Department for Energy and Climate Change, production of natural gas from the Leman fields was of the order $10^{8}$ kg per month in 2014 (https://itportal.decc.gov.uk/pprs/report3.pdf, accessed January 2016), which will be almost entirely $\mathrm{CH}_{4}$. The emission calculated here is equivalent to approximately 1.8 to $3.3 \times 10^{7} \mathrm{~kg}$ per month, and would be about 18 to $33 \%$ of the total production if it were continuously emitting, which would be a similar or greater percentage loss to that calculated in Karion et al. [2013]. If the source emitted for only $10 \%$ or $1 \%$ of the time, it would equate to about 2 to $3 \%$ or 0.2 to $0.3 \%$ of the total Leman field production. We do not know for how long this source was emitting, or even whether it is a leak from the North Sea gas industry (see later sections). The methane release from venting in the Leman fields from the 2014 NAEI point sources inventory is $1.7 \times 10^{6} \mathrm{~kg}$ $\mathrm{yr}^{-1}$, or about $0.1 \%$ of the total $\mathrm{CH}_{4}$ production.

\subsection{Pseudo-Observations Estimate}

Another way to estimate the $\mathrm{CH}_{4}$ emission responsible for the observed enhancement is to use computer modeling to generate so-called pseudo-observations. In this case, we transport $\mathrm{CH}_{4}$ emissions using the modeled winds to see if we can reproduce the details observed during the box flights. The method is explained in Section 3.

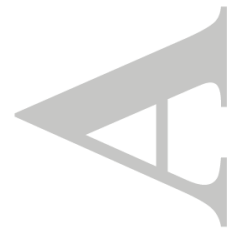

(C)2017 American Geophysical Union. All Rights Reserved. 
The footprint in Figure 4 follows a northerly track around the high-pressure system. Emissions from the sea, or from land principally around Yorkshire and Lincolnshire (where the highest particle densities are, marked in the darkest blue), or both, are likely to have contributed to the higher levels of $\mathrm{CH}_{4}$ measured in the plume.

Figure 5a shows the increment above the background arising from using the annual mean NAEI UK emissions from 2012 in solid black, with the key emission sectors shown in green, blue and brown. With these emissions we find an increase above the Mace Head background of about 40 to $50 \mathrm{ppb}$. This is consistent with the mole fraction difference measured between our North Sea background $\mathrm{CH}_{4}$ of 1913 ppb, measured along flight leg IJ upwind of our target area, and 1865 ppb, the North Atlantic background measured at Mace Head. So, the NAEI emissions are consistent with the $\mathrm{CH}_{4}$ measured along IJ, but fail to capture the strong enhancements seen in $\mathrm{AB}, \mathrm{CD}, \mathrm{EF}$ and $\mathrm{GH}$.

In order to reproduce the observed peaks in $\mathrm{CH}_{4}$ (red crosses in Figure 5), an emission from a North Sea gas field region was added on top of the NAEI emissions. The gas field region would in reality contain many point sources. Here, we represent the total emission from all the point sources as a simple area average. An emission of $1 \times 10^{-8} \mathrm{~kg} \mathrm{~m}^{-2} \mathrm{~s}^{-1}$ was released between $1.6^{\circ} \mathrm{E}$ and $2.2^{\circ} \mathrm{E}$, and $53.3^{\circ} \mathrm{N}$ and $53.5^{\circ} \mathrm{N}$ (the thin white rectangle shown in Figure 4b), where Vulcan and other gas fields are located. The emission rate calculated in Section 4.2, using the mass balance approach, is slightly lower than this, ranging between 1.9 and $6.4 \times 10^{-9} \mathrm{~kg} \mathrm{~m}^{-2} \mathrm{~s}^{-1}$. If the emission rate and area from the mass balance calculation were applied here, the results would underestimate the $\mathrm{CH}_{4}$ peaks by tens to $100 \mathrm{ppb}$. The difference is likely to be because the mass balance approach involves making many assumptions to model a simple box with uniform wind, whereas (C)2017 American Geophysical Union. All Rights Reserved. 
NAME models the 3D transport based on the meteorological analyses. For the pseudoobservations, the emissions are defined to best reproduce the $\mathrm{CH}_{4}$ measurements. The black dashed line in Figure 5a shows the result of this calculation. The model reproduces the height and width of the peaks well, suggesting that a local source could explain the magnitude and structure seen in the observations.

In summary, our modeling indicates that the FGGA $\mathrm{CH}_{4}$ data are consistent with inflow from the North Atlantic, which is being enhanced by UK emissions of $\mathrm{CH}_{4}$ as this air mass passes over land. As the air mass then passes over the North Sea, potential offshore sources can further increase the mole fraction of $\mathrm{CH}_{4}$ in the air mass. According to this explanation, the observed "troughs" during the transects have $\mathrm{CH}_{4}$ mole fractions consistent with outflow from the UK. The peaks correspond to this outflow combined with additional sources, which we hypothesise as coming from gas rigs in the North Sea. The dashed line in Figure 5a shows that this combination of emissions produces qualitatively good pseudo-observations. Analysis of the $\mathrm{CH}_{4}$ isotopologue data is investigated in the following section to further test this hypothesis.

\subsection{Source Identification Using Carbon Isotopes in $\mathbf{C H}_{4}$}

In addition to the FGGA data, flask and Tedlar bag samples of ambient air were also collected during the flight for subsequent analysis in the laboratory. $\mathrm{CH}_{4}$ mole fractions measured in the laboratory on these samples by CRDS were entirely consistent with the FGGA data (Figure 6a). Flask and bag sample collection was also triggered when the FGGA detected the large $\mathrm{CH}_{4}$ spikes (¿2050ppb), which were observed very close to gas

rigs, as discussed above.

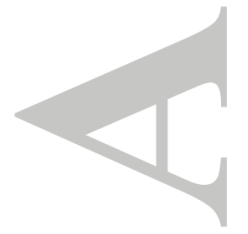

(C)2017 American Geophysical Union. All Rights Reserved. 
The $\delta^{13} \mathrm{C}-\mathrm{CH}_{4}$ isotopic signature was measured in the air samples, providing an additional constraint on the likely source of the elevated $\mathrm{CH}_{4}$. Gas supplied from the southern North Sea and distributed in SE England and the Netherlands has an isotopic signature between -37 and $-30 \%$, in contrast to -60 to $-50 \%$ for landfill and waste sources, and -67 to $-58 \%$ for agricultural emissions [Lowry et al., 2001; Zazzeri et al., 2015]. The isotopic signatures from three deep bituminous coal mines in Yorkshire were recently measured to be in the range of -45 to $-49 \%$ [Zazzeri et al., 2016]. The average UK emission is $-58 \pm$ $3 \%$ based on values in [Zazzeri, 2016; Zazzeri et al., 2015, 2016]. For a more detailed breakdown of source signatures, see e.g. France et al. [2016]; Zazzeri et al. [2015].

Flasks collected at Mace Head on the West coast of Ireland at 14:00 UTC on the same day contained $1865 \pm 1 \mathrm{ppb} \mathrm{CH}_{4}$ with a $\delta^{13} \mathrm{C}^{-\mathrm{CH}_{4}}$ of $-47.37 \pm 0.08 \%$ [ White et al., 2017]. Averaging the six samples with the lowest mole fractions provides a North Sea background of $1915 \mathrm{ppb}$ with $\delta^{13} \mathrm{C}-\mathrm{CH}_{4}-47.56 \pm 0.12 \%$. The isotopic difference between the Mace Head background and the North Sea background is in agreement with the proposed UK mixed source of $-58 \pm 3 \%$.

Figure $6 \mathrm{~b}$ shows the $\delta^{13} \mathrm{C}-\mathrm{CH}_{4}$ time series, while Figure 7 shows a Keeling plot from the data (the inverse of the $\mathrm{CH}_{4}$ mole fraction plotted against the $\delta^{13} \mathrm{C}-\mathrm{CH}_{4}$ ), which can reveal the isotopic origin of the measured $\mathrm{CH}_{4}$ plume in its y-intercept [Pataki, 2003]. The intercept and uncertainty were calculated for all Keeling plots from a BCES (bivariate correlated errors and intrinsic scatter) orthogonal regression, with a bootstrap resampling from 1000 simulations using the method developed by Akritas and Bershady [1996]. This takes into account the measurement uncertainties in both $\mathrm{x}$ and $\mathrm{y}$ axis measurements and allows for heteroscedastic distribution of data. Unless otherwise stated, this method (C)2017 American Geophysical Union. All Rights Reserved. 
is used for all the isotopic source signatures calculated here. Details of the use of this method for Keeling plot analysis are given by Zazzeri et al. [2015].

The data in Figure 7 are divided into samples from the short-lived $\mathrm{CH}_{4}$ spikes, which we classify as strongly influenced by very local sources (hollow triangles), and samples that are representative of the plume (filled circles). The $\mathrm{CH}_{4}$ spikes are defined as elevations of ¿20 ppb in FGGA $\mathrm{CH}_{4}$ measurements with a duration of between 10 and 60 seconds.

If bags were collected during these spikes on the FGGA record then they were separated as presumed to be influenced by a local source. An isotopic source signature of $-31.5 \pm$ $3.2 \%$ was calculated based on two samples in the highest single $\mathrm{CH}_{4}$ spike (which was along $\mathrm{AB}$ ) and one sample directly before it for a background. This signature clearly identifies this $\mathrm{CH}_{4}$ as being due to very local emissions from the rigs. Values of $-31.7 \pm 0.1$ $\%$ and $-34.0 \pm 1.8 \%$ were calculated for spikes along EF and GH. There were not enough data points to do bootstrapping for these spike calculations, so the BCES regression was performed without bootstrapping. Although there is large uncertainty because of the few data points in the $\mathrm{CH}_{4}$ spikes, this value is consistent with the value from flight B809 of $-33.0 \pm 1.0 \%$ (see Section 4.1 and supporting material). In contrast, a regression line of the plume data (filled circles) gives a $\delta^{13} \mathrm{C}^{-} \mathrm{CH}_{4}$ isotopic signature of $-52.2 \pm 1.8 \%$, which is not indicative of our hypothesised gas rig source alone. It could be representative of $\mathrm{CH}_{4}$ from the area of Yorkshire highlighted by the footprint (Figure 4), as there are known emitting coal mines, coal-fired power stations and gas-fired power stations, and the region therefore has a larger fossil contribution than nationally.

Using the y-intercept of a Keeling plot to identify the $\delta^{13} \mathrm{C}^{-} \mathrm{CH}_{4}$ of a source effectively assumes a single source of $\mathrm{CH}_{4}$, or at least that the source can be described by that one

(C)2017 American Geophysical Union. All Rights Reserved. 
value for $\delta^{13} \mathrm{C}-\mathrm{CH}_{4}$. However, there could potentially be several different emission sources with different signatures. If these sources were well mixed before the measurement points, they would still form a straight line along the Keeling plot. The profiles show there is a well-mixed layer (Figure 2). The modeling discussion in the previous section suggests that we have measured air that has come from the North Atlantic, then picked up emissions over the UK, followed by emissions from over the North Sea, all of which mix, and which manifests in our measurements close to the surface of the North Sea as a plume of $\mathrm{CH}_{4}$. Superimposed on this are a few narrow spikes consistent with very recent local gas rig emissions. Another candidate for the source of the broader plume of $\mathrm{CH}_{4}$ is UK landbased emissions, although it is unclear as to why this was not observed upwind of the gas rig area. One explanation for that could be that the broader plume is consistent with a short-term pulse of land-based emissions, which we sampled by chance over the gas rigs we were targeting.

Figure 4, showing the recent 24-hour boundary layer footprint, indicates that the air reaching our target area had crossed the United Kingdom and left the UK close to the south Humber area. This is a region with mixed agricultural sources, as well as some large energy generation plants. Potentially, the Humber estuary itself could be a source of biogenic $\mathrm{CH}_{4}$ [Upstill-Goddard et al., 2000]. Coastal regions can also be a source of $\mathrm{CH}_{4}$, for example Borges et al. [2016] reported high $\mathrm{CH}_{4}$ emissions from the Belgian coastal zone of the North Sea. However those emissions were two orders of magnitude smaller than what would be required to explain our observations. Other studies have measured methane leaking from abandoned North Sea wells, however only a small fraction reaches the atmosphere. Vielstädte et al. [2015] found that only $2 \%$ (about $280 \mathrm{~kg} \mathrm{yr}^{-1}$ ) of the (C)2017 American Geophysical Union. All Rights Reserved. 
methane released from three abandoned wells between Scotland and Norway reached the atmosphere. Schneider von Deimling et al. [2015] observed biogenic methane seeping from another abandoned well site in the northern North Sea. Most of the methane released remained below the thermocline, and only about $7.0 \times 10^{5} \mathrm{~kg} \mathrm{yr}^{-1}$ reached the atmosphere, which is at lease two orders of magnitude smaller than required to explain our case.

As a simple test for potential missing coastal sources, we repeated the NAME pseudoobservations calculations using the NAEI emissions described above, but in this case assumed further sources of $\mathrm{CH}_{4}$ of $1 \times 10^{-7} \mathrm{~kg} \mathrm{~m}^{-2} \mathrm{~s}^{-1}$, or $28 \mathrm{~kg} \mathrm{~s}^{-1}$, (a rate at least 10 times higher than the NAEI inventory average for this area) from two individual model grid boxes in this region, box 1 covering 53.8 to $53.9^{\circ} \mathrm{N}$ and $0.2^{\circ} \mathrm{W}$ to $0.0^{\circ} \mathrm{E}$, and box 2 covering 53.9 to $54.0^{\circ} \mathrm{N}$ and $0.2^{\circ} \mathrm{W}$ to $0.0^{\circ} \mathrm{E}$ (see Figure $4 \mathrm{~b}$ for the outlines of the boxes). Figure 5b shows the resulting pseudo-observations. It is clear that something approximating this source can also explain the observations qualitatively, although the width of the modeled peaks suggests a smaller spatial source than has been tested here. The other key difference is that these pseudo-observations create a peak during the upwind leg IJ (from time 15.32 to 15.58$)$, which is not seen in the observations. These results imply that a correctly-timed intermittent point source of emissions, such as a power station, could explain the observed plume.

A further possibility is that various mainland and offshore sources have already been well mixed by the time we sampled the air. For example, an approximation of the bulk signature of multiple sources that have mixed together can be made using the following equation [France et al., 2016]:

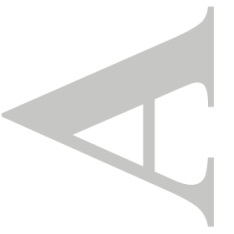

(C)2017 American Geophysical Union. All Rights Reserved. 


$$
\delta^{13} C_{b u l k}=\delta^{13} C_{x}[X \%]+\delta^{13} C_{y}[Y \%]
$$

where $\delta^{13} \mathrm{C}_{\text {bulk }}$ is the bulk signature (as determined by the Keeling plot), and $\mathrm{X}$ and Y represent different component sources of $\mathrm{CH}_{4}$. In this case, a simple calculation can be made to test whether a mixture of land-based emissions could combine with gas rig emissions to plausibly generate the observed bulk signature of $-52 \%$. Two sources are assumed: a UK average source of $-58 \%$ (discussed above), which is represented in the model by the NAEI; and a gas rigs source with a signature of $-32 \%$. Using these values, a relative proportion of $75 \%$ NAEI emissions and $25 \%$ gas rigs emissions (or other emissions with this isotopic signature) would result in a bulk signature of $-52 \%$.

To further investigate the plausibility of such a mixture, correlations between $\mathrm{CH}_{4}$ and $\mathrm{CO}$ and $\mathrm{CO}_{2}$ are shown in Figure 8, with each transect being shown by a different color. There is a positive correlation between all the tracers, however the slope is shallower for IJ in Figures $8 \mathrm{~b}$ and c, meaning there is relatively more $\mathrm{CH}_{4}$ seen in all transects downwind of IJ. This suggests an additional source observed only downwind of IJ, which emits relatively more $\mathrm{CH}_{4}$, but still emits $\mathrm{CO}$ and $\mathrm{CO}_{2}$. Gas flaring emissions contain relatively more $\mathrm{CH}_{4}$ than other fossil fuel burning (based on the NAEI inventory), but would be even more enriched in ${ }^{13} \mathrm{C}$ than fugitive gas. Above $2000 \mathrm{ppb}$ of $\mathrm{CH}_{4}$, the $\mathrm{CO}$ and $\mathrm{CO}_{2}$ remain fairly flat, implying the source of the highest peaks in methane are not burning sources, which would emit $\mathrm{CO}$ and $\mathrm{CO}_{2}$. Fugitive gas from the rigs would be consistent with this. Figure 8c, shows evidence of an emission along $\mathrm{CD}$, which was relatively rich in $\mathrm{CO}$, and was not sampled on the other transects. This transect was furthest downwind

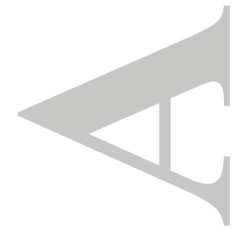

(C)2017 American Geophysical Union. All Rights Reserved. 
and likely did not fully sample the plume under investigation, so has not been used in the mass balance calculation.

\section{Discussion}

On 19 August 2013, a plume of $\mathrm{CH}_{4}$ was measured in-situ by the FAAM BAe-146 atmospheric research aircraft, flown in a box pattern around the Leman gas field in the North Sea. The distinct plume was observed only downwind of the Leman field, suggesting that the field could be the source of the $\mathrm{CH}_{4}$. Applying a simple box model to the area, a $\mathrm{CH}_{4}$ emission rate to the atmosphere of between $2.5 \pm 0.8 \times 10^{4}$ to $4.6 \pm 1.5 \times 10^{4}$ $\mathrm{kg} \mathrm{h} \mathrm{h}^{-1}$ was calculated, depending on the assumptions made. This is 40 to $75 \%$ of the rate calculated by Karion et al. [2013] using a similar method on an oil and gas field in Utah, and would be about 18 to $33 \%$ of the total natural gas produced by the Leman gas fields in 2014, if emitting continuously. The European gas industries aim for a leak rate of $0.5 \%$ from extraction to delivery to the customer, therefore this would be in excess of their target. However, if the source is a one off pulse or is emitting less than about $1 \%$ of the time, it would be below the target.

A North Sea gas field source in addition to the NAEI emissions was able to reproduce qualitativêly good pseudo-observations using the NAME dispersion model. However, analysis of $\delta^{13} \mathrm{C}^{-\mathrm{CH}_{4}}$ showed that the $\mathrm{CH}_{4}$ plume had an isotopic signature of $-53 \%$. If the plume was entirely from the gas field, it would be approximately $-32 \%$, according to isotopic analysis of the localised spikes in $\mathrm{CH}_{4}$ in the immediate vicinity of the platforms.

Land-based emissions from the UK are on average $-58 \%$ however this area of Yorkshire is likely to have a heavier signature due to the presence of coal mines and power stations.

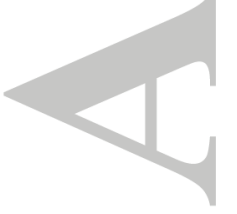

(C)2017 American Geophysical Union. All Rights Reserved. 
Therefore the bulk signature of $-53 \%$ could be representative of the land-based emissions of this region.

Correlations between $\mathrm{CH}_{4}$ and $\mathrm{CO}$ and $\mathrm{CO}_{2}$ support the hypothesis of the $\mathrm{CH}_{4}$ plume being predominantly from sources that also emit $\mathrm{CO}$ and $\mathrm{CO}_{2}$, and the spikes in $\mathrm{CH}_{4}$ being fugitive gas from North Sea platforms. The slopes in Figure 8 indicate that the upwind transect, IJ, sampled a different mixture of emissions than the downwind transects, which had relatively more $\mathrm{CH}_{4}$.

There are many possible combinations of locations and strengths of emission that would explain the observations, and it is not possible to conclude unequivocally which is correct. We propose two likely explanations for the source of $\mathrm{CH}_{4}$ that is not represented in the NAEI annual emissions inventory.

1. An additional source on land, likely to be a point source (e.g. a power station), however it is not certain why this would be absent from the flight transect furthest upwind (IJ). Small-scale features, for instance land and sea breezes, could explain this discrepancy, as they would not be captured in the meteorological model used to model the transport. Or, it may be the result of a pulse of emissions, which was sampled by chance. If the additional source were from a power plant, the isotopic signature is likely to be heavier than the UK average of $-58 \%$, and therefore consistent with the observed signature of

\section{$-53 \%$}

2. A mixture of emissions from the land and from gas rigs, which resulted in the observed bulk signature. A simple isotopic analysis suggests that up to about $25 \%$ of the $\mathrm{CH}_{4}$ could be from natural gas $(-32 \%)$ and still be consistent with the observed bulk

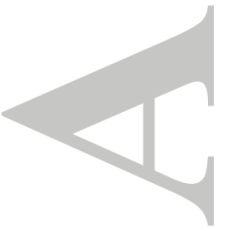

(C)2017 American Geophysical Union. All Rights Reserved. 
signature. Therefore the majority of the $\mathrm{CH}_{4}$ that is unaccounted for would still have to be from biogenic sources (unless a lighter biogenic gas is also present).

This work has demonstrated the importance of using isotopic analysis in addition to observations of mole fractions of $\mathrm{CH}_{4}$ in identifying sources. Isotopic measurements can help constrain the emission source, and can be useful for evaluating bottom-up inventories, such as the NAEI. For planning of future flights with similar objectives, it is further recommended that vertical profiles, both upwind and downwind of a source under investigation, are flown. This would allow for a better characterisation of the vertical structure and mixing of any emissions. Measurements of other trace gases would also help identify the source. Our measurements of $\mathrm{CO}$ and $\mathrm{CO}_{2}$ have helped to distinguish the local emissions from the gas field from the UK plume. In addition, ethane is a component of natural gas, but not emitted by agriculture or landfill. Combining measurements of $\mathrm{CH}_{4}$, ethane, carbon monoxide, carbon dioxide and carbon isotopes in $\mathrm{CH}_{4}$ would be an improved strategy for identifying sources.

Had the isotopic analysis not been performed, the likely conclusion of this work would have been of a gas field source of $\mathrm{CH}_{4}$. We caution, therefore, of the importance of understanding the limitations of the conclusions that can be drawn from a data set. In this particular case, the simplest explanation appears to be incorrect.

Acknowledgments. The MAMM project was funded by the UK Natural Environment Research Council (Grant NE/I029293/1).

JAP and MC also acknowledge support through the ERC ACCI project, project number 267760 .

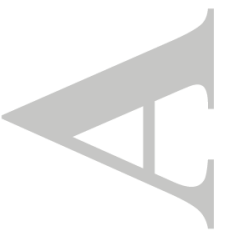

(C)2017 American Geophysical Union. All Rights Reserved. 
IP acknowledges support from MOCA, funded by the Research Council of Norway, grant 225814.

Airborne data was obtained using the BAe-146-301 Atmospheric Research Aircraft [ARA] flown by Directflight Ltd and managed by the Facility for Airborne Atmospheric Measurements [FAAM], which is a joint entity of the Natural Environment Research Council $[\mathrm{NERC}]$ and the Met Office.

We specifically acknowledge the cooperation and effort of Professor S. O'Doherty and

Dr. D. Young (University of Bristol) for the $\mathrm{CH}_{4}$ measurements from the AGAGE Mace Head station. The operation at Mace Head is funded by the UK Department of Business, Energy and Industrial Strategy (formerly the Department of Energy and Climate Change) through contract GA01103 with additional funding at Mace Head under NASA contract NNX11AF17G through MIT with a sub award 5710002970 to University of Bristol.

Data will be available through http://catalogue.ceda.ac.uk/uuid/03b040a422a4b694a90252410613 or requested through direct contact with the corresponding author.

\section{References}

Akritas, M. G., and M. A. Bershady (1996), Linear Regression for Astronomical Data with Measurement Errors and Intrinsic Scatter, Astrophys. J., 470, 706, doi:10.1086/177901.

Allen, G., H. Coe, A. Clarke, C. Bretherton, R. Wood, S. J. Abel, P. Barrett, P. Brown, R. George, S. Freitag, C. McNaughton, S. Howell, L. Shank, V. Kapustin, V. Brekhovskikh, L. Kleinman, Y. N. Lee, S. Springston, T. Toniazzo, R. Krejci, J. Fochesatto, G. Shaw, P. Krecl, B. Brooks, G. McMeeking, K. N. Bower, P. I. Williams, J. Crosier, I. Crawford, P. Connolly, J. D. Allan, D. Covert, A. R. Bandy, L. M. Russell, (C)2017 American Geophysical Union. All Rights Reserved. 
J. Trembath, M. Bart, J. B. McQuaid, J. Wang, and D. Chand (2011), South East Pacific atmospheric composition and variability sampled along $20^{\circ} \mathrm{S}$ during VOCALS-REx, Atmos. Chem. Phys., 11(11), 5237-5262, doi:10.5194/acp-11-5237-2011.

Ashfold, M. J., N. R. P. Harris, A. J. Manning, A. D. Robinson, N. J. Warwick, and J. A. Pyle (2014), Estimates of tropical bromoform emissions using an inversion method, Atmos. Chem. Phys., 14(2), 979-994, doi:10.5194/acp-14-979-2014.

Bergamaschi, P., S. Houweling, A. Segers, M. Krol, C. Frankenberg, R. A. Scheepmaker, E. Dlugokencky, S. C. Wofsy, E. A. Kort, C. Sweeney, T. Schuck, C. Brenninkmeijer, H. Chen, V. Beck, and C. Gerbig (2013), Atmospheric $\mathrm{CH}_{4}$ in the first decade of the 21st century: Inverse modeling analysis using SCIAMACHY satellite retrievals and NOAA surface measurements, J. Geophys. Res. Atmos., 118(13), 7350-7369, doi: $10.1002 /$ jgrd.50480.

Borges, A. V., W. Champenois, N. Gypens, B. Delille, and J. Harlay (2016), Massive marine methane emissions from near-shore shallow coastal areas., Sci. Rep., 6, 27,908, doi:10.1038/srep27908.

Bousquet, P., P. Ciais, J. B. Miller, E. J. Dlugokencky, D. A. Hauglustaine, C. Prigent, G. R. Van der Werf, P. Peylin, E.-G. Brunke, C. Carouge, R. L. Langenfelds, J. Lathière, F. Papa, M. Ramonet, M. Schmidt, L. P. Steele, S. C. Tyler, and J. White (2006), Contribution of anthropogenic and natural sources to atmospheric methane variability., Nature, 443(7110), 439-43, doi:10.1038/nature05132.

Conley, S., G. Franco, I. Faloona, D. R. Blake, J. Peischl, and T. B. Ryerson (2016), Methane emissions from the 2015 Aliso Canyon blowout in Los Angeles, CA, Science,

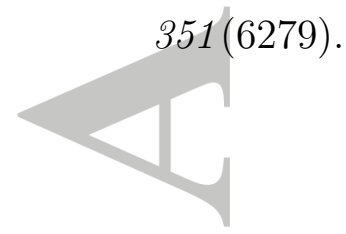

(C)2017 American Geophysical Union. All Rights Reserved. 
Cullen, M. (1993), The unified forecast/climate model, Meteorological Magazine, 122(1449), 81-94.

Dee, D. P., S. M. Uppala, A. J. Simmons, P. Berrisford, P. Poli, S. Kobayashi, U. Andrae, M. A. Balmaseda, G. Balsamo, P. Bauer, P. Bechtold, A. C. M. Beljaars, L. van de Berg, J. Bidlot, N. Bormann, C. Delsol, R. Dragani, M. Fuentes, A. J. Geer, L. Haimberger, S. B. Healy, H. Hersbach, E. V. Hólm, L. Isaksen, P. Kållberg, M. Köhler, M. Matricardi, A. P. McNally, B. M. Monge-Sanz, J.-J. Morcrette, B.-K. Park, C. Peubey, P. de Rosnay, C. Tavolato, J.-N. Thépaut, and F. Vitart (2011), The ERA-Interim reanalysis: configuration and performance of the data assimilation system, Q. J. R. Meteorol. Soc., $137(656)$, 553-597, doi:10.1002/qj.828.

Dlugokencky, E. J. (2003), Atmospheric methane levels off: Temporary pause or a new steady-state?, Geophys. Res. Lett., 30(19), 1992, doi:10.1029/2003GL018126.

Dlugokencky, E. J. (2005), Conversion of NOAA atmospheric dry air $\mathrm{CH}_{4}$ mole fractions to a gravimetrically prepared standard scale, J. Geophys. Res., $110(\mathrm{D} 18)$, D18,306, doi:10.1029/2005JD006035.

Etminan, M., G. Myhre, E. J. Highwood, and K. P. Shine (2016), Radiative forcing of carbon dioxide, methane, and nitrous oxide: A significant revision of the methane radiative forcing, Geophys. Res. Lett., 43(24), 12,614-12,623, doi:10.1002/2016GL071930.

Fiore, A. M., L. W. Horowitz, E. J. Dlugokencky, and J. J. West (2006), Impact of meteorology and emissions on methane trends, 19902004, Geophys. Res. Lett., 33(12), L12,809, doi:10.1029/2006GL026199.

Fisher, R., D. Lowry, O. Wilkin, S. Sriskantharajah, and E. G. Nisbet (2006), Highprecision, automated stable isotope analysis of atmospheric methane and carbon diox(C)2017 American Geophysical Union. All Rights Reserved. 
ide using continuous-flow isotope-ratio mass spectrometry, Rapid Commun. Mass Spectrom., 20(2), 200-208, doi:10.1002/rcm.2300.

France, J. L., M. Cain, R. E. Fisher, D. Lowry, G. Allen, S. J. O’Shea, S. Illingworth, J. Pyle, N. Warwick, B. T. Jones, M. W. Gallagher, K. Bower, M. Le Breton, C. Percival, J. Muller, A. Welpott, S. Bauguitte, C. George, G. D. Hayman, A. J. Manning, C. L. Myhre, M. Lanoisellé, and E. G. Nisbet (2016), Measurements of $\delta^{13} \mathrm{C}$ in $\mathrm{CH}_{4}$ and using particle dispersion modeling to characterize sources of Arctic methane within an air mass, J. Geophys. Res. Atmos., doi:10.1002/2016JD026006.

Gerbig, C., S. Schmitgen, D. Kley, A. Volz-Thomas, K. Dewey, and D. Haaks (1999), An improved fast-response vacuum-UV resonance fluorescence CO instrument, J. Geophys. Res. Atmos., 104(D1), 1699-1704, doi:10.1029/1998JD100031.

Jones, A., D. Thomson, M. Hort, and B. Devenish (2007), The U.K. Met Office's NextGeneration Atmospheric Dispersion Model, NAME III, in Air Pollution Modeling and its Application XVII (Proceedings of the 27th NATO/CCMS International Technical Meeting on Air Pollution Modelling and its Application), pp. 580-589, Springer US, Boston, MA, doi:10.1007/978-0-387-68854-1_62.

Karion, A., C. Sweeney, G. Pétron, G. Frost, R. Michael Hardesty, J. Kofler, B. R. Miller, T. Newberger, S. Wolter, R. Banta, A. Brewer, E. Dlugokencky, P. Lang, S. A. Montzka, R. Schnell, P. Tans, M. Trainer, R. Zamora, and S. Conley (2013), Methane emissions estimate from airborne measurements over a western United States natural gas field, Geophys. Res. Lett., 40(16), 4393-4397, doi:10.1002/grl.50811.

Karion, A., C. Sweeney, E. A. Kort, P. B. Shepson, A. Brewer, M. Cambaliza, S. A. Conley, K. Davis, A. Deng, M. Hardesty, S. C. Herndon, T. Lauvaux, T. Lavoie, D. Lyon, (C)2017 American Geophysical Union. All Rights Reserved. 
T. Newberger, G. Pétron, C. Rella, M. Smith, S. Wolter, T. I. Yacovitch, and P. Tans (2015), Aircraft-Based Estimate of Total Methane Emissions from the Barnett Shale Region, Environ. Sci. Technol., 49(13), 8124-8131, doi:10.1021/acs.est.5b00217.

Lewis, A. C., M. J. Evans, J. R. Hopkins, S. Punjabi, K. A. Read, R. M. Purvis, S. J. Andrews, S. J. Moller, L. J. Carpenter, J. D. Lee, A. R. Rickard, P. I. Palmer, and M. Parrington (2013), The influence of biomass burning on the global distribution of selected non-methane organic compounds, Atmos. Chem. Phys., 13(2), 851-867, doi: 10.5194/acp-13-851-2013.

Lowry, D., C. W. Holmes, N. D. Rata, P. O'Brien, and E. G. Nisbet (2001), London methane emissions: Use of diurnal changes in concentration and $\delta^{13} \mathrm{C}$ to identify urban/sources and verify inventories, J. Geophys. Res. Atmos., 106(D7), 7427-7448, doi: 10.1029/2000JD900601.

Manning, A. J., S. O’Doherty, A. R. Jones, P. G. Simmonds, and R. G. Derwent (2011), Estimating UK methane and nitrous oxide emissions from 1990 to 2007 using an inversion modeling approach, J. Geophys. Res., 116(D2), D02,305, doi: 10.1029/2010JD014763.

McNorton, J., M. P. Chipperfield, M. Gloor, C. Wilson, W. Feng, G. D. Hayman, M. Rigby, P. B. Krummel, S. O’Doherty, R. G. Prinn, R. F. Weiss, D. Young, E. Dlugokencky, and S. A. Montzka (2016), Role of OH variability in the stalling of the global atmospheric $\mathrm{CH}_{4}$ growth rate from 1999 to 2006, Atmos. Chem. Phys., 16(12), 79437956, doi:10.5194/acp-16-7943-2016.

Myhre, G., D. Shindell, F.-M. Bréon, W. Collins, J. Fuglestvedt, J. Huang, D. Koch, J.-F. Lamarque, D. Lee, B. Mendoza, T. Nakajima, A. Robock, G. Stephens, T. Take(C)2017 American Geophysical Union. All Rights Reserved. 
mura, and H. Zhan (2013), Anthropogenic and Natural Radiative Forcing, in Clim. Chang. 2013 Phys. Sci. Basis. Contrib. Work. Gr. I to Fifth Assess. Rep. Intergov. Panel Clim. Chang., chap. 8, pp. 659-740, Cambridge University Press, doi:10.1017/ CBO9781107415324.018.

Nisbet, E. G., E. J. Dlugokencky, M. R. Manning, D. Lowry, R. E. Fisher, J. L. France, S. E. Michel, J. B. Miller, B. Vaughn, P. Bousquet, J. A. Pyle, M. Cain, R. Brownlow, G. Zazzeri, A. C. Manning, C. Labuschagne, E. W. Wolff, R. Holloway, A. Administration, A. Sciences, L. Road, and C. Sciences (2016), Rising atmospheric methane: 2007-14 growth and isotopic shift, Global Biogeochem. Cycles, pp. 1-60, doi: 10.1002/2016GB005406.

O'Sheă, S. J., S. J.-B. Bauguitte, M. W. Gallagher, D. Lowry, and C. J. Percival (2013), Development of a cavity-enhanced absorption spectrometer for airborne measurements of $\mathrm{CH}_{4}$ and $\mathrm{CO}_{2}$, Atmos. Meas. Tech., 6(5), 1095-1109, doi:10.5194/amt-6-1095-2013.

O'Shea, S. J., G. Allen, M. W. Gallagher, K. Bower, S. M. Illingworth, J. B. A. Muller, B. T. Jones, C. J. Percival, S. J.-B. Bauguitte, M. Cain, N. Warwick, A. Quiquet, U. Skiba, J. Drewer, K. Dinsmore, E. G. Nisbet, D. Lowry, R. E. Fisher, J. L. France, M. Aurela, A. Lohila, G. Hayman, C. George, D. B. Clark, A. J. Manning, A. D. Friend, and J. Pyle (2014), Methane and carbon dioxide fluxes and their regional scalability for the European Arctic wetlands during the MAMM project in summer 2012, Atmos. Chem. Phys., 14 (23), 13,159-13,174, doi:10.5194/acp-14-13159-2014.

Pataki, D. E. (2003), The application and interpretation of Keeling plots in terrestrial carbon cycle research, Global Biogeochem. Cycles, 17(1), doi:10.1029/2001GB001850.

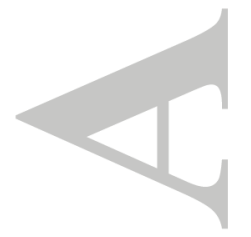

(C)2017 American Geophysical Union. All Rights Reserved. 
Paul, J. B., L. Lapson, and J. G. Anderson (2001), Ultrasensitive absorption spectroscopy with a high-finesse optical cavity and off-axis alignment, Appl. Opt., 40(27), 4904, doi: 10.1364/AO.40.004904.

Polson, D., D. Fowler, E. Nemitz, U. Skiba, A. McDonald, D. Famulari, C. Di Marco, I. Simmons, K. Weston, and R. Purvis (2011), Estimation of spatial apportionment of greenhouse gas emissions for the UK using boundary layer measurements and inverse modelling technique, Atmos. Environ., 45(4), 1042-1049, doi: 10.1016/j.atmosenv.2010.10.011.

Prinn, R. G., R. F. Weiss, P. J. Fraser, P. G. Simmonds, D. M. Cunnold, F. N. Alyea, S. O’Doherty, P. Salameh, B. R. Miller, J. Huang, R. H. J. Wang, D. E. Hartley, C. Harth, L. P. Steele, G. Sturrock, P. M. Midgley, and A. McCulloch (2000), A history of chemically and radiatively important gases in air deduced from ALE/GAGE/AGAGE, J. Geophys. Res. Atmos., 105(D14), 17,751-17,792, doi: $10.1029 / 2000 \mathrm{jd} 900141$.

Rigby, M., S. A. Montzka, R. G. Prinn, J. W. C. White, D. Young, S. O’Doherty, M. F. Lunt, A. L. Ganesan, A. J. Manning, P. G. Simmonds, P. K. Salameh, C. M. Harth, J. Mühle, R. F. Weiss, P. J. Fraser, L. P. Steele, P. B. Krummel, A. McCulloch, and S. Park (2017), Role of atmospheric oxidation in recent methane growth., Proc. Natl. Acad. Sci. U. S. A., p. 201616426, doi:10.1073/pnas.1616426114.

Saunois, M., P. Bousquet, B. Poulter, A. Peregon, P. Ciais, J. G. Canadell, E. J. Dlugokencky, G. Etiope, D. Bastviken, S. Houweling, G. Janssens-Maenhout, F. N. Tubiello, S. Castaldi, R. B. Jackson, M. Alexe, V. K. Arora, D. J. Beerling, P. Bergamaschi, D. R. Blake, G. Brailsford, V. Brovkin, L. Bruhwiler, C. Crevoisier, P. Crill, K. Covey, (C)2017 American Geophysical Union. All Rights Reserved. 
C. Curry, C. Frankenberg, N. Gedney, L. Höglund-Isaksson, M. Ishizawa, A. Ito, F. Joos, H.-S. Kim, T. Kleinen, P. Krummel, J.-F. Lamarque, R. Langenfelds, R. Locatelli, T. Machida, S. Maksyutov, K. C. McDonald, J. Marshall, J. R. Melton, I. Morino, V. Naik, S. O’Doherty, F.-J. W. Parmentier, P. K. Patra, C. Peng, S. Peng, G. P. Peters, I. Pison, C. Prigent, R. Prinn, M. Ramonet, W. J. Riley, M. Saito, M. Santini, R. Schroeder, I. J. Simpson, R. Spahni, P. Steele, A. Takizawa, B. F. Thornton, H. Tian, Y. Tohjima, N. Viovy, A. Voulgarakis, M. van Weele, G. R. van der Werf, R. Weiss, C. Wiedinmyer, D. J. Wilton, A. Wiltshire, D. Worthy, D. Wunch, X. Xu, Y. Yoshida, B. Zhang, Z. Zhang, and Q. Zhu (2016), The global methane budget 2000-2012, Earth Syst. Sci. Data, 8(2), 697-751, doi:10.5194/essd-8-697-2016.

Schaefer, H., S. E. M. Fletcher, C. Veidt, K. R. Lassey, G. W. Brailsford, T. M. Bromley, E. J. Dlugokencky, S. E. Michel, J. B. Miller, I. Levin, D. C. Lowe, R. J. Martin, B. H. Vaughn, and J. W. C. White (2016), A 21st-century shift from fossil-fuel to biogenic methane emissions indicated by ${ }^{13} \mathrm{CH}_{4}$, Science, 352(6281).

Schneider von Deimling, J., P. Linke, M. Schmidt, and G. Rehder (2015), Ongoing methane discharge at well site 22/4b (North Sea) and discovery of a spiral vortex bubble plume motion, Mar. Pet. Geol., 68, 718-730, doi:10.1016/j.marpetgeo.2015.07.026.

Schwietzke, S., O. A. Sherwood, L. M. P. Bruhwiler, J. B. Miller, G. Etiope, E. J. Dlugokencky, S. E. Michel, V. A. Arling, B. H. Vaughn, J. W. C. White, and P. P. Tans (2016), Upward revision of global fossil fuel methane emissions based on isotopic database, $\mathrm{Na}$ ture, 538(7623), 88-91, doi:10.1038/nature19797.

Turner, A. J., D. J. Jacob, J. Benmergui, S. C. Wofsy, J. D. Maasakkers, A. Butz, O. Hasekamp, and S. C. Biraud (2016), A large increase in U.S. methane emissions (C)2017 American Geophysical Union. All Rights Reserved. 
over the past decade inferred from satellite data and surface observations, Geophys. Res. Lett., 43(5), 2218-2224, doi:10.1002/2016GL067987.

Turner, A. J., C. Frankenberg, P. O. Wennberg, and D. J. Jacob (2017), Ambiguity in the causes for decadal trends in atmospheric methane and hydroxyl., Proc. Natl. Acad. Sci. U. S. A., p. 201616020 , doi:10.1073/pnas.1616020114.

Upstill-Goddard, R. C., J. Barnes, T. Frost, S. Punshon, and N. J. P. Owens (2000), Methane in the southern North Sea: Low-salinity inputs, estuarine removal, and atmospheric flux, Global Biogeochem. Cycles, 14(4), 1205-1217, doi:10.1029/1999GB001236.

Vielstädte, L., J. Karstens, M. Haeckel, M. Schmidt, P. Linke, S. Reimann, V. Liebetrau, D. F. McGinnis, and K. Wallmann (2015), Quantification of methane emissions at abandoned gas wells in the Central North Sea, Mar. Pet. Geol., 68, 848-860, doi: 10.1016/j.marpetgeo.2015.07.030.

White, J., B. Vaughn, and S. Michel (2017), Stable isotopic composition of atmospheric methane $\left({ }^{13} \mathrm{C}\right)$ from the NOAA ESRL Carbon Cycle Cooperative Global Air Sampling Network, 1998-2015, version: 2017-01-20, path: ftp://aftp.cmdl.noaa.gov/data/trace_gases/ch4c13/flask/.

Zazzeri, G. (2016), Methane emissions in the UK: Deciphering regional sources with mobile measurements and isotopic characterisation, Ph.D. thesis.

Zazzeri, G., D. Lowry, R. Fisher, J. France, M. Lanoisellé, and E. Nisbet (2015), Plume mapping and isotopic characterisation of anthropogenic methane sources, Atmos. Environ., 110, 151-162, doi:10.1016/j.atmosenv.2015.03.029.

Zazzeri, G., D. Lowry, R. E. Fisher, J. L. France, M. Lanoisellé, B. F. J. Kelly, J. M. Necki, C. P. Iverach, E. Ginty, M. Zimnoch, A. Jasek, and E. G. Nisbet (2016), Carbon isotopic (C)2017 American Geophysical Union. All Rights Reserved. 
signature of coal-derived methane emissions to the atmosphere: from coalification to alteration, Atmos. Chem. Phys, 16, 13,669-13,680, doi:10.5194/acp-16-13669-2016.

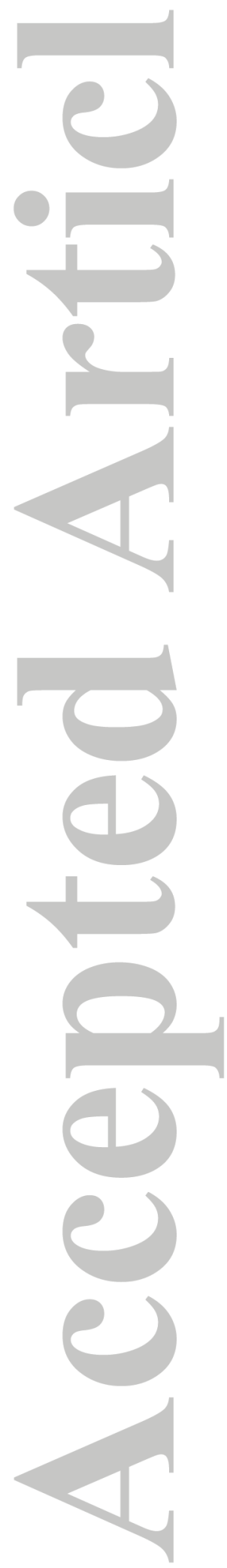



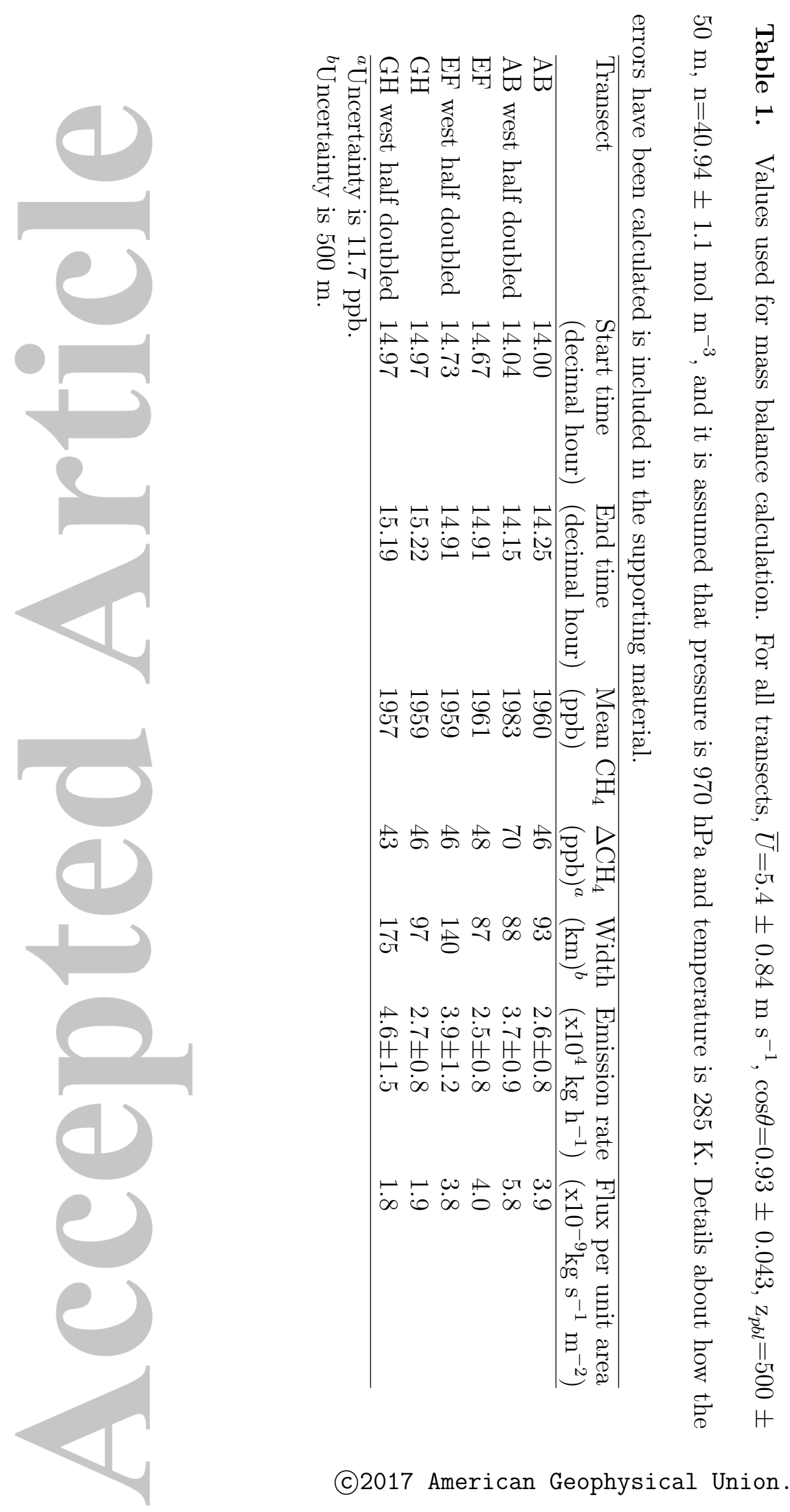

(C)2017 American Geophysical Union. All Rights Reserved. 


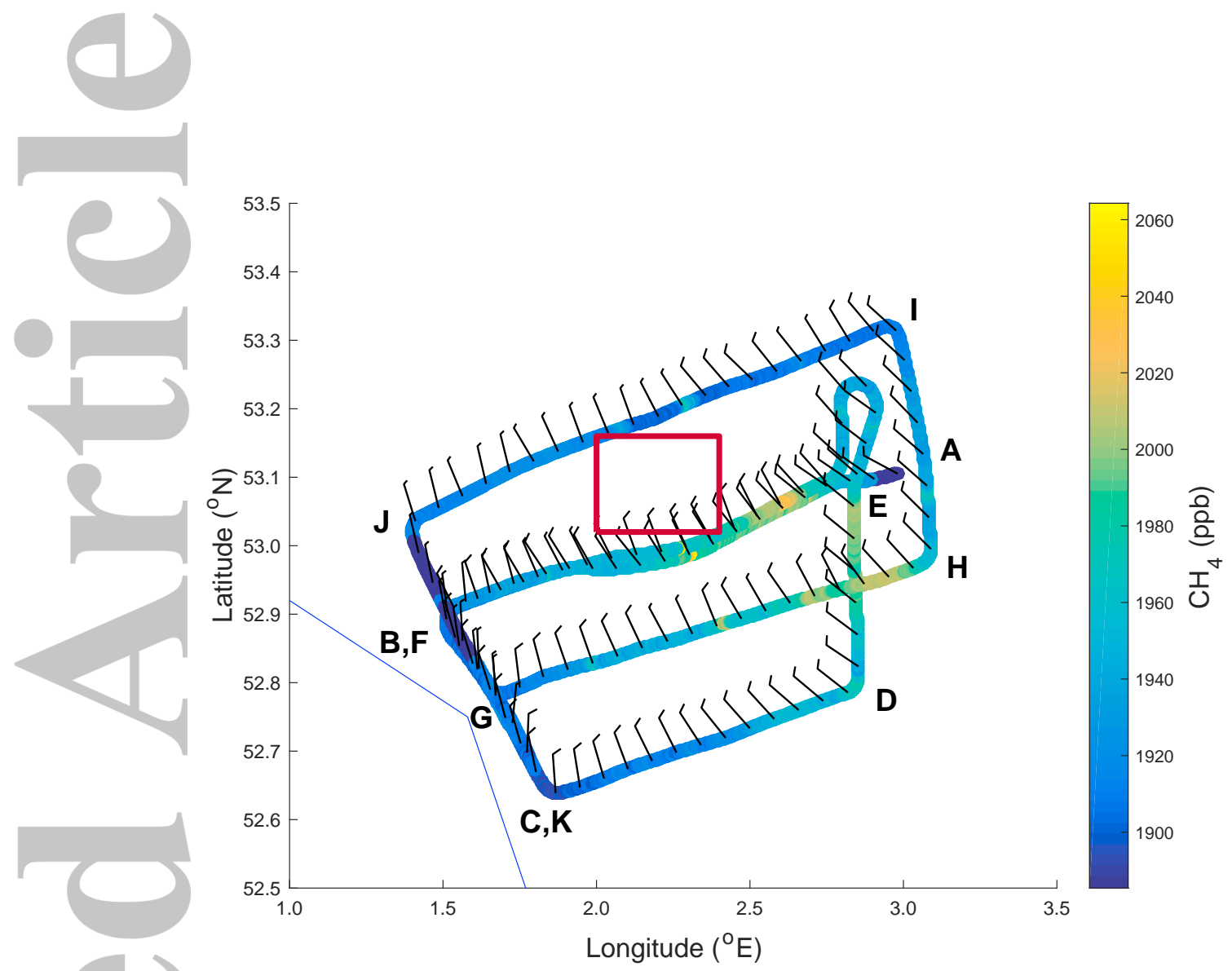

Figure 1. FGGA measurements of $\mathrm{CH}_{4}(\mathrm{ppb})$ along the track of flight $\mathrm{B} 802$. Wind barbs are plotted in black. Letters label the sequence in which the pattern was flown. The maroon box marks the approximate area of the Leman field, which was the target of this flight (referred to in the text as the Leman target area). The time elapsed between point A (about 14:00 UTC) and point K (about 15:45 UTC) was about 1 hour 45 minutes. The thin blue line represents the coast of East Anglia. 

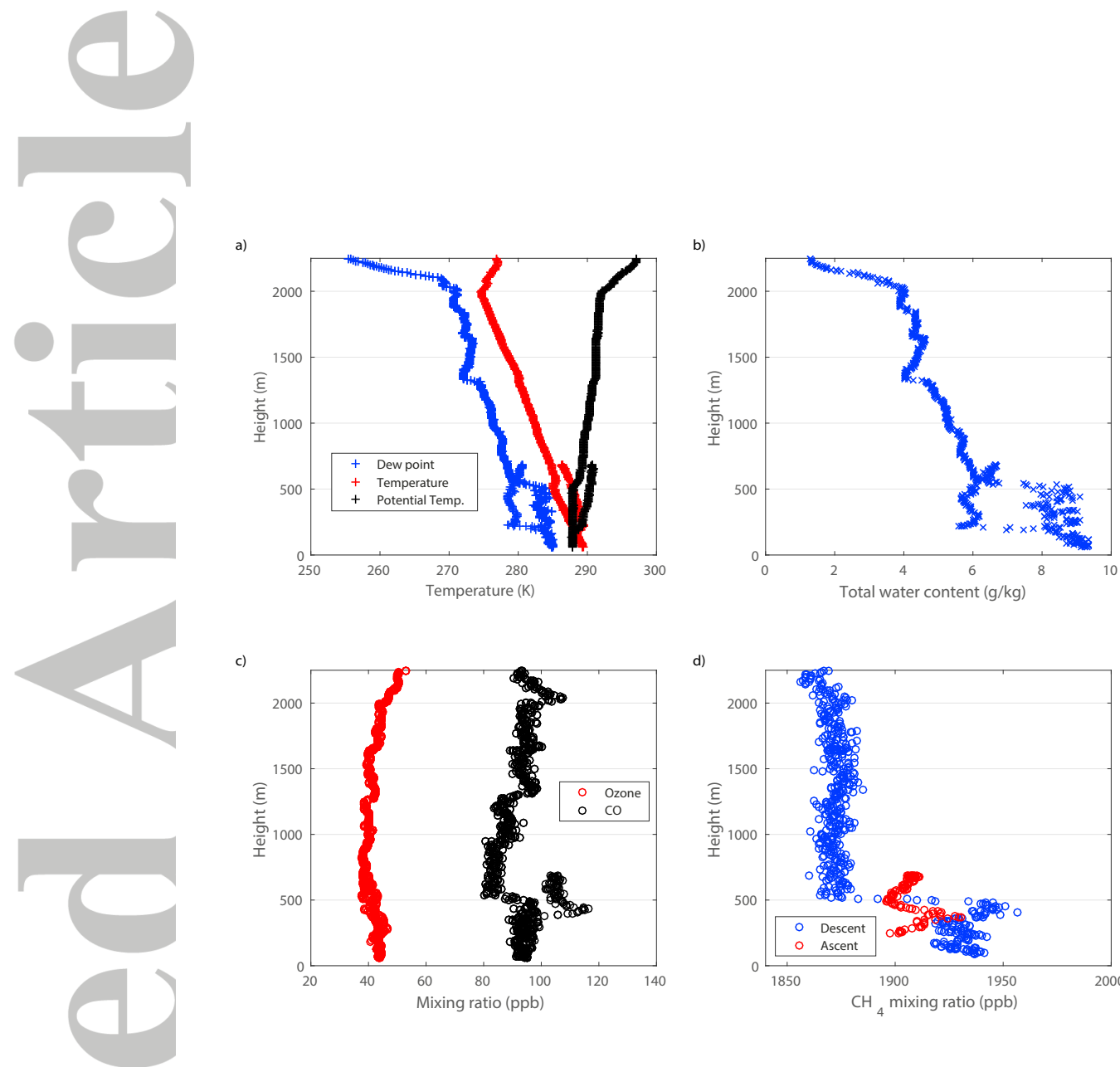

Figure 2. Vertical structure measured in the area of interest during flight B802. (a) Dew point temperature (blue crosses), temperature (red crosses) and potential temperature (black crosses). (b) Total water content (blue crosses). (c) Ozone (red circles) and carbon monoxide (black circles) mixing ratios. (d) $\mathrm{CH}_{4}$ mixing ratios during the descent (blue circles) to point $\mathrm{A}$ from above $2 \mathrm{~km}$, and the ascent out of point $\mathrm{K}$ to about $700 \mathrm{~m}$ (red circles).

(C)2017 American Geophysical Union. All Rights Reserved. 

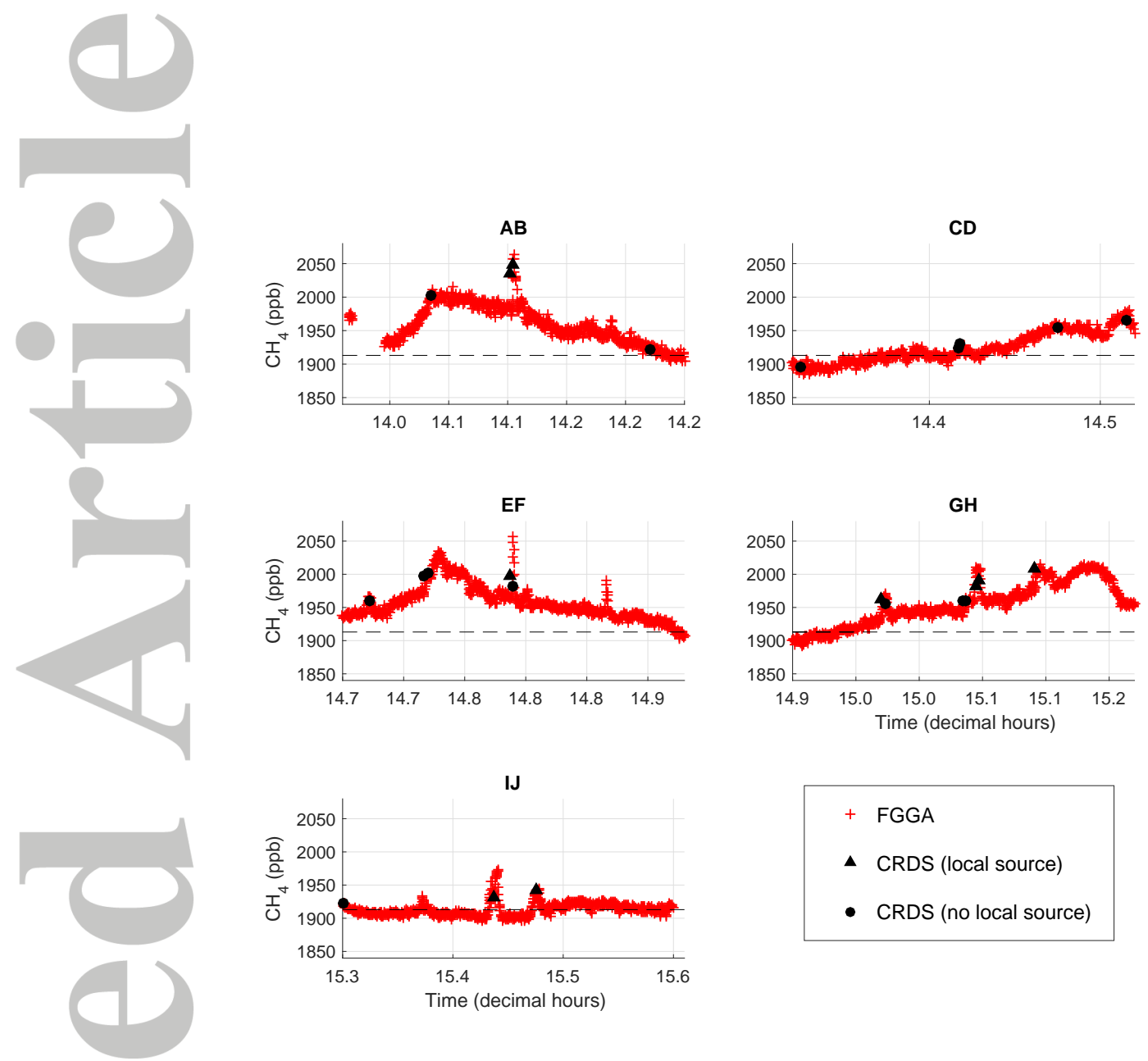

Figure 3. $\mathrm{CH}_{4}$ mole fraction (ppb) for flight legs $\mathrm{AB}, \mathrm{CD}, \mathrm{EF}, \mathrm{GH}$ and IJ. In situ measurements from the FGGA are shown by red crosses, and air samples analyzed by CRDS are shown by the black symbols. Circles denote samples taken in the wider plume, triangles are from the narrow spikes influenced by local sources. The dashed line shows the background calculated by averaging $\mathrm{CH}_{4}$ along IJ. Time is in UTC. 


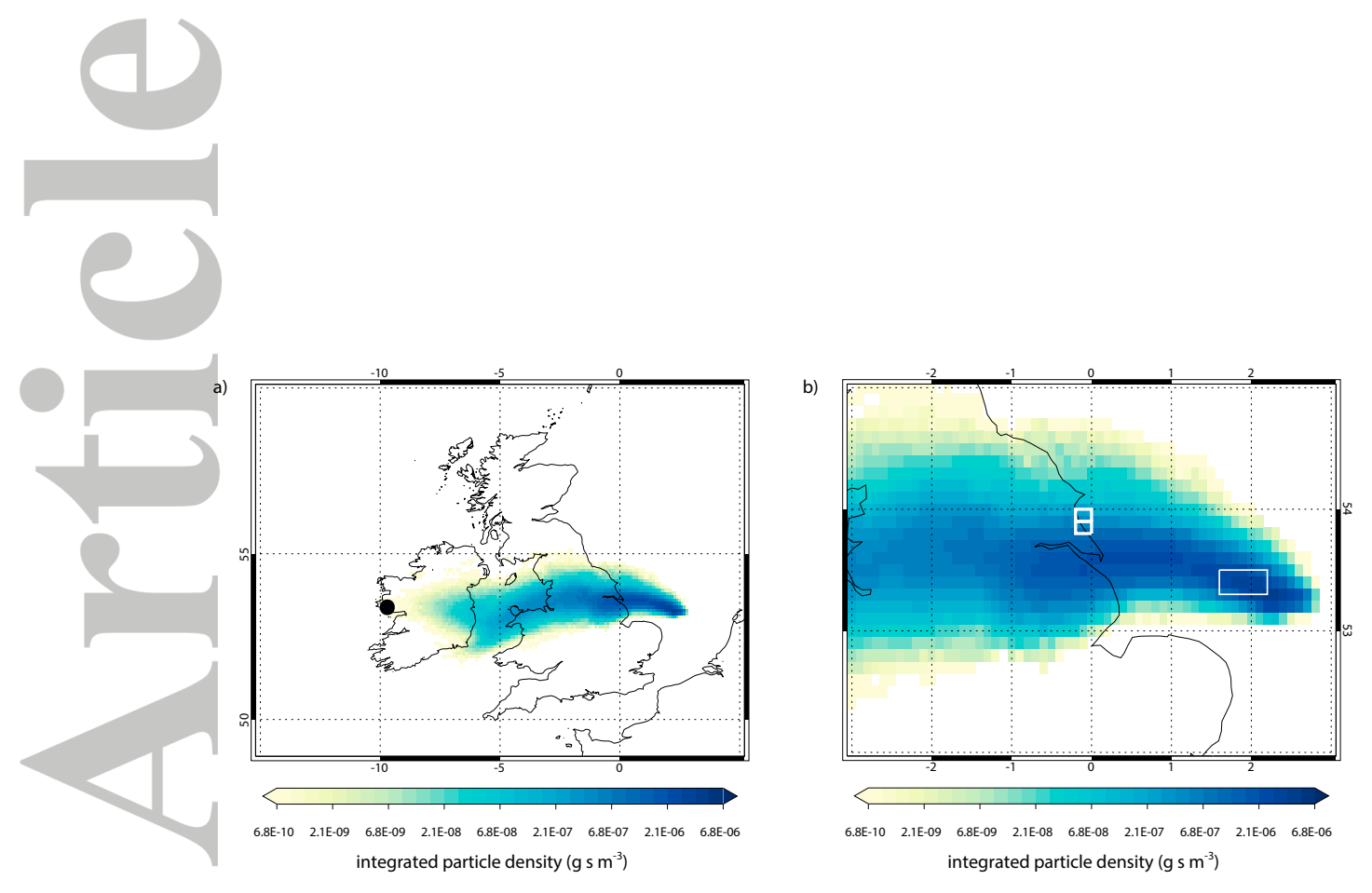

Figure 4. Boundary layer footprint, during the 24 hours prior to the flight, of trajectories released backwards in time from one location along the flight track in the target area. The footprint is the time-integrated particle density of particles that are in the PBL over the 24 hours prior to the particle release point. A footprint was calculated for each 5-minute segment of the flight track. Figure $4 \mathrm{~b}$ is a zoomed in area of $4 \mathrm{a}$, which also shows the "gas rig" emissions region (thin white rectangle), and the "land emission boxes" (two thick white boxes). Mace Head Observatory is marked by the black circle in Figure 4a.

(C)2017 American Geophysical Union. All Rights Reserved. 


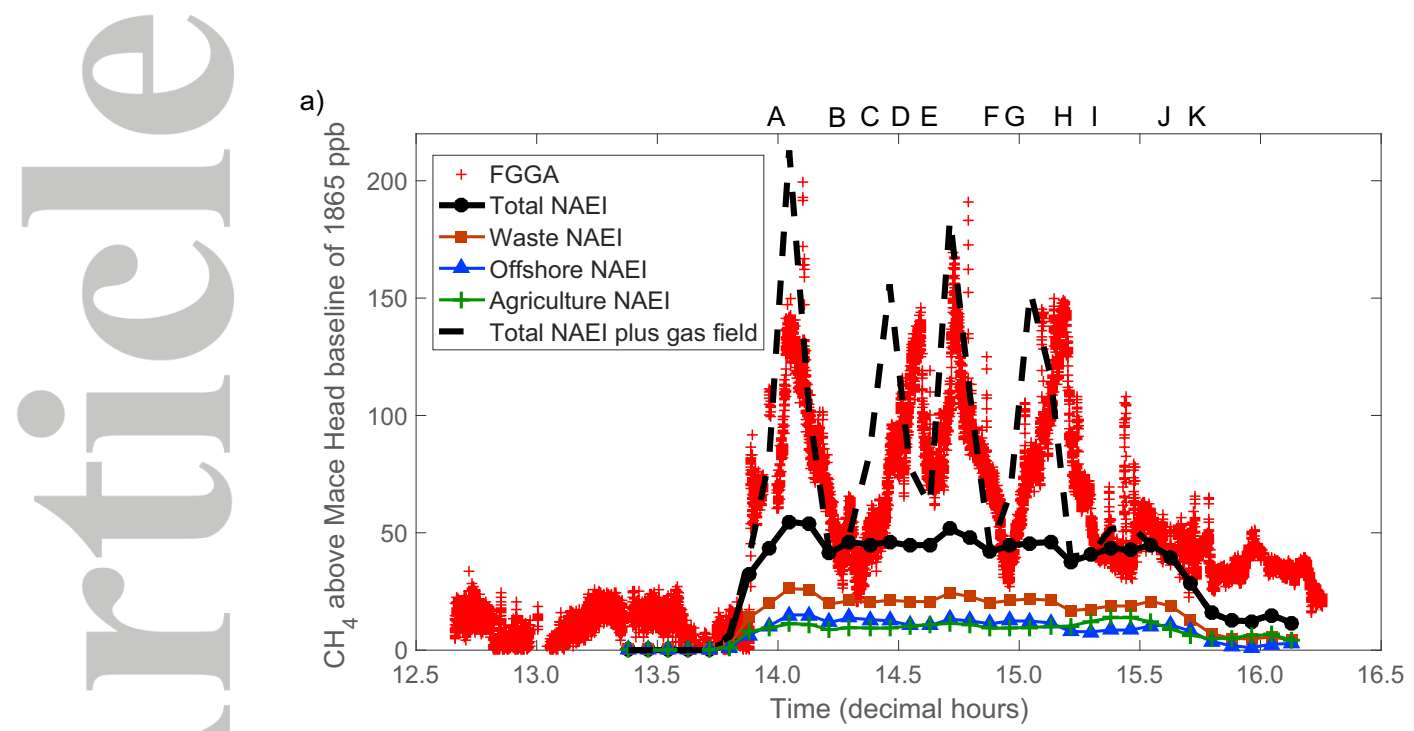

b)

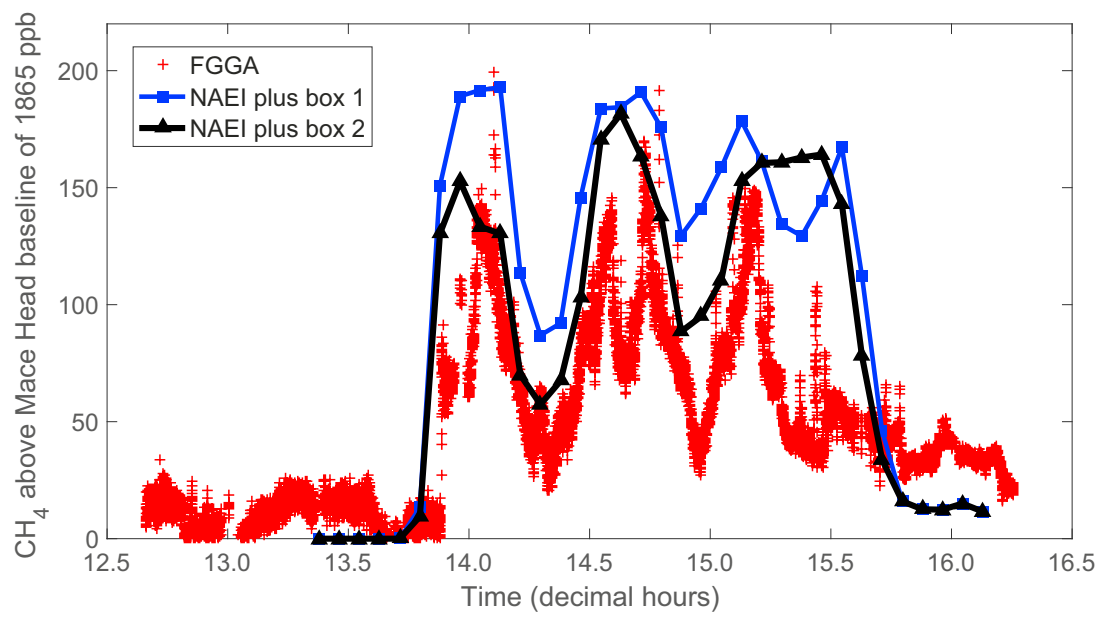

Figure 5. (a) Time series of the increment of $\mathrm{CH}_{4}$ above the baseline (1865 ppb, from Mace Head the previous day) for the FGGA measurements (red crosses) and the calculated pseudo-observations using various emissions. Annual mean total NAEI emissions were used to calculate the pseudo-observations shown by the black solid line. The three main contributing sectors to the total NAEI are also shown: waste (brown), offshore (blue) and agriculture (green). The dashed black line shows the result when the NAEI emissions are added to the areal gas field emissions. Letters show the locations marked in Figure 1. (b) Annual mean NAEI emissions are used to create pseudo-observations (again using a background value of $1865 \mathrm{ppb}$ from Mace Head the previous day), except for 2 small areas where the NAEI emissions are replaced with a higher emission rate of $1 \times 10^{-7} \mathrm{~kg} \mathrm{~m}^{-} 2 \mathrm{~s}^{-1}$. Box 1 is 53.8 to $54.0^{\circ} \mathrm{N}$, and $0.2^{\circ} \mathrm{W}$ to $0.0^{\circ} \mathrm{E}$. Box 2 is 53.8 to $54.0^{\circ} \mathrm{N}$, and $0.2^{\circ} \mathrm{W}$ to $0.0^{\circ} \mathrm{E}$, as shown in figure $4 \mathrm{~b}$.

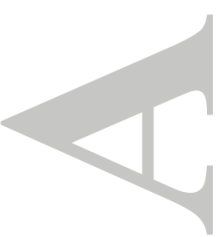

(C)2017 American Geophysical Union. All Rights Reserved. 

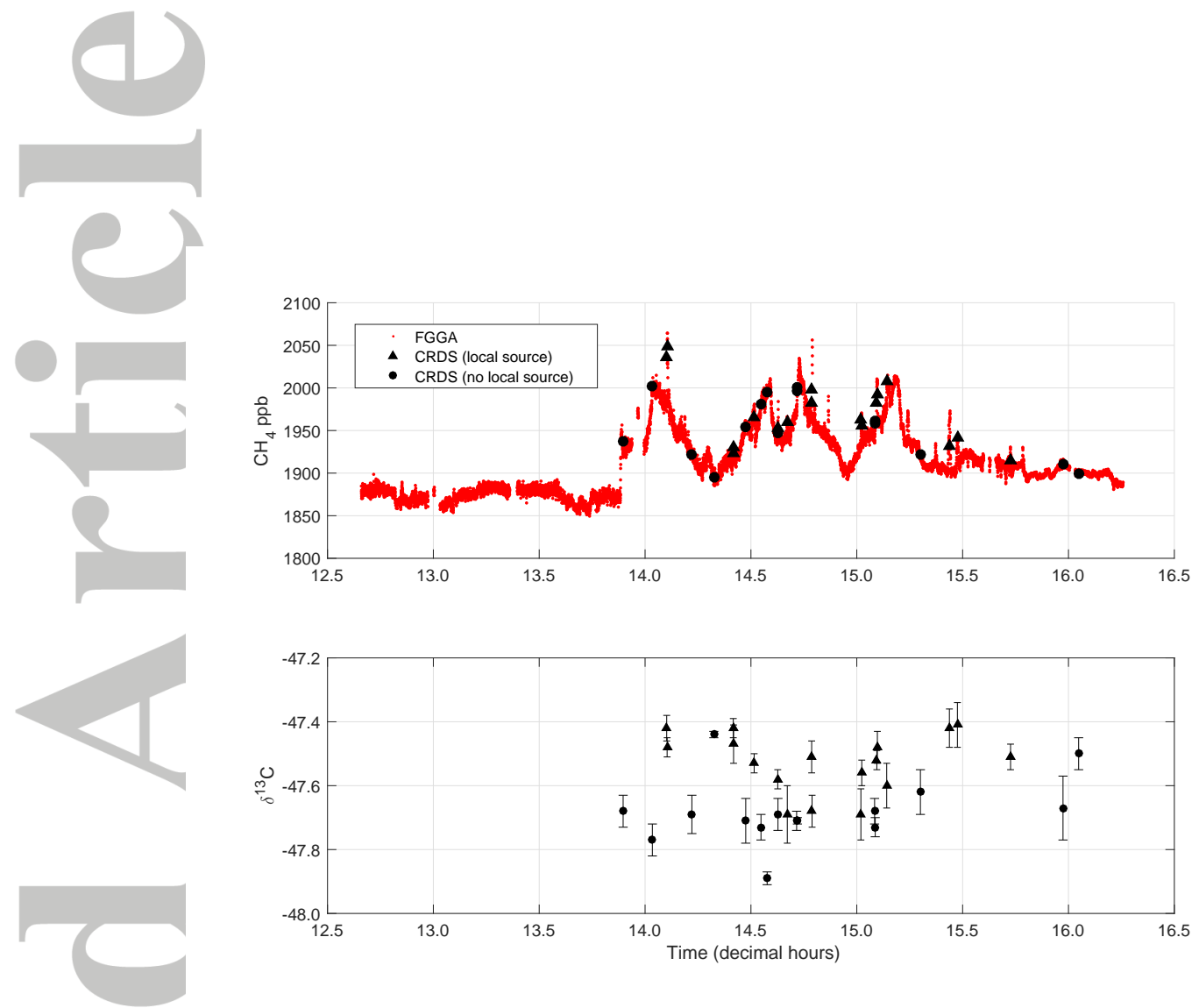

Figure 6. (a) $\mathrm{CH}_{4}$ measurements (ppb) during Flight B802, in situ from the FGGA (red dots), and from bag and canister samples analyzed using CRDS (black triangles when during a narrow spike in $\mathrm{CH}_{4}$ which has been influenced by local sources, black circles otherwise). (b) Time series of the $\delta^{13} \mathrm{C}_{\text {in }} \mathrm{CH}_{4}(\%)$ measured in triplicate from each sample, with the standard deviation represented by error bars. For CRDS data, only samples taken within the planetary boundary layer are shown. Time is in UTC.
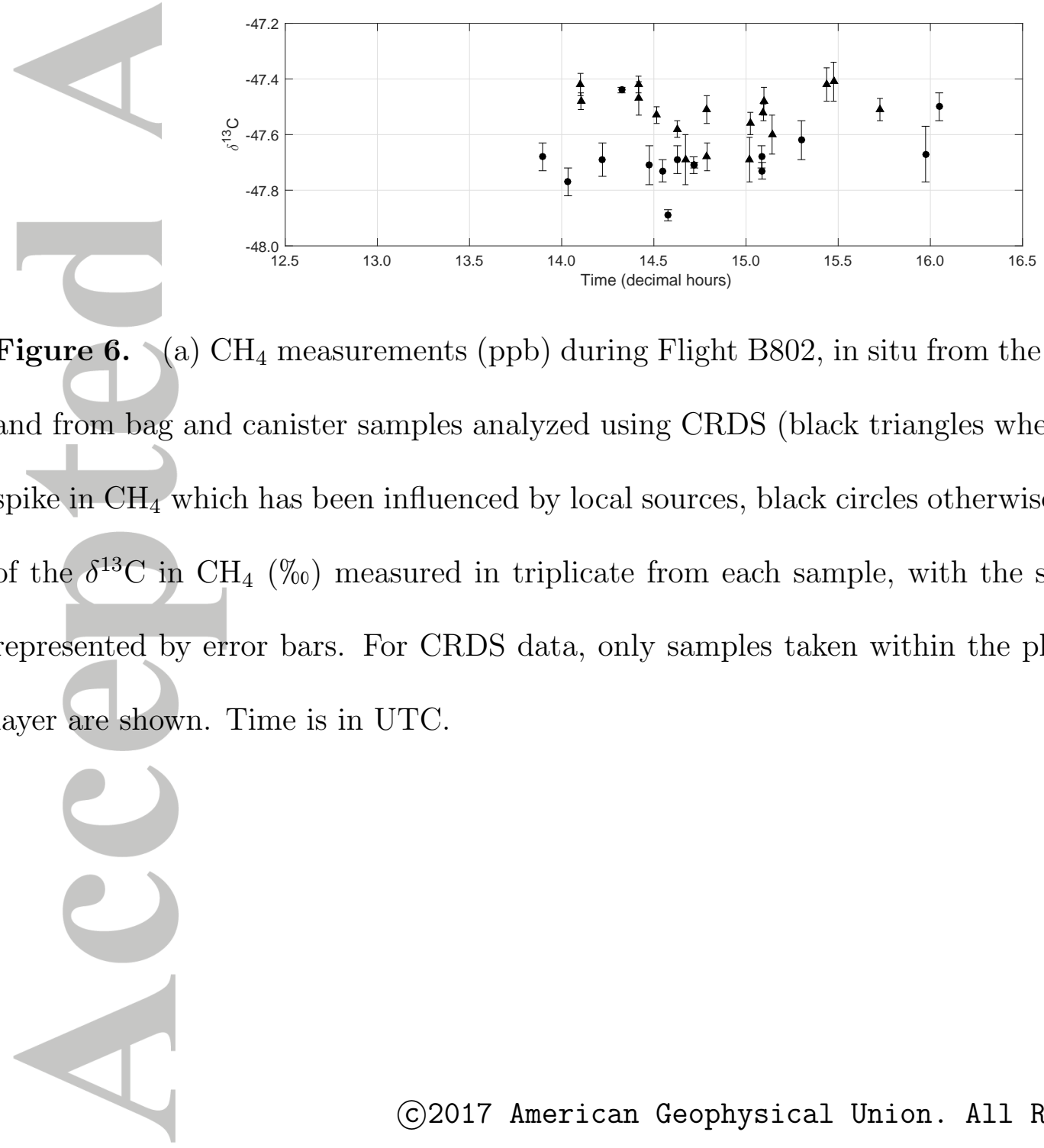


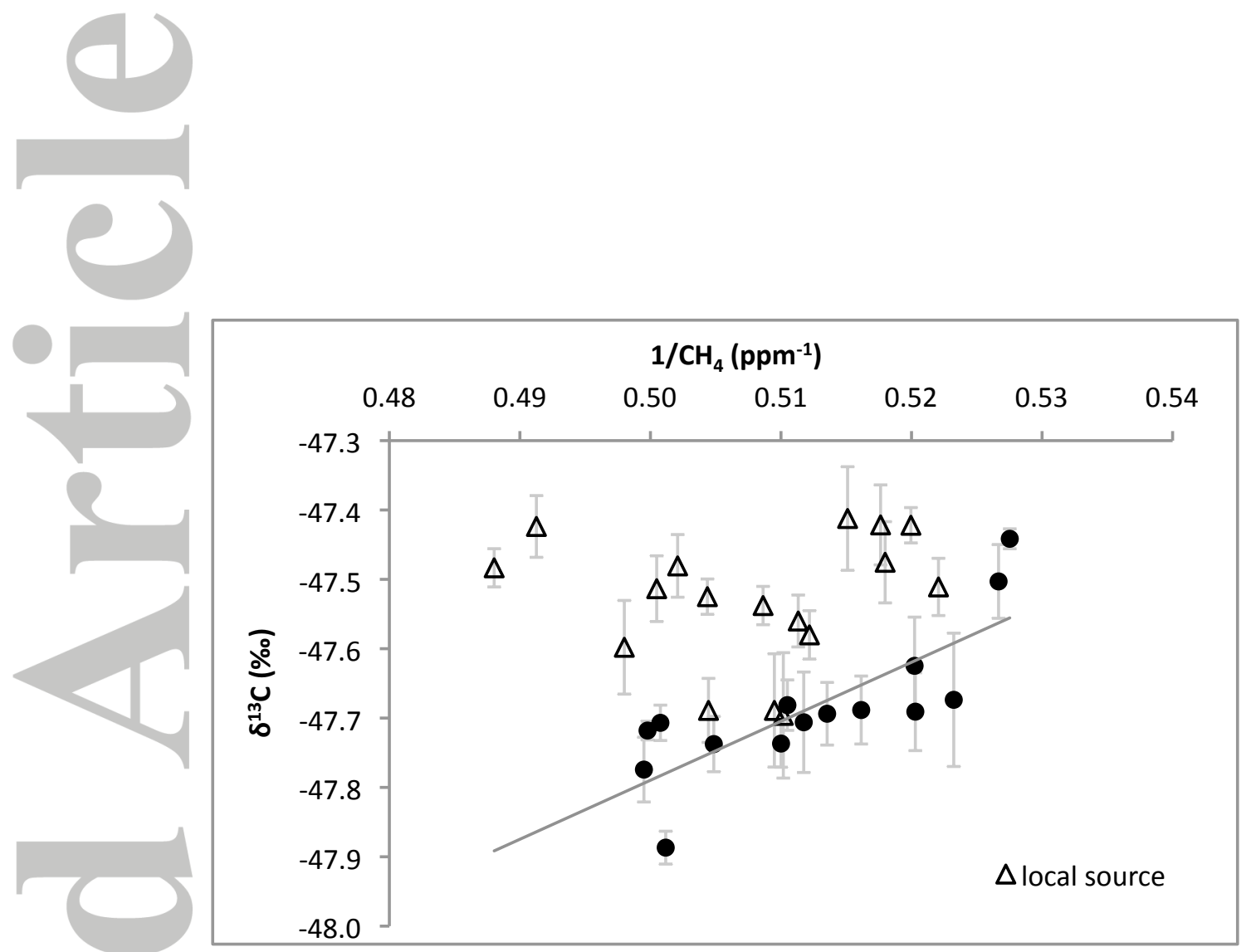

Figure 7. Keeling plot identifying the isotopic signature of the elevated $\mathrm{CH}_{4}$. If the points collected during the local short lived gas spikes are omitted then an isotopic signature of -52.2 $\pm 1.8 \%$ is determined (a predominantly biogenic source). The points collected in the gas spikes (hollow triangles) indicate addition of $\mathrm{CH}_{4}$ from a local source. For the regression shown for points away from the local source, $\mathrm{R}^{2}$ is 0.637 , giving a correlation with pi 0.001 . 

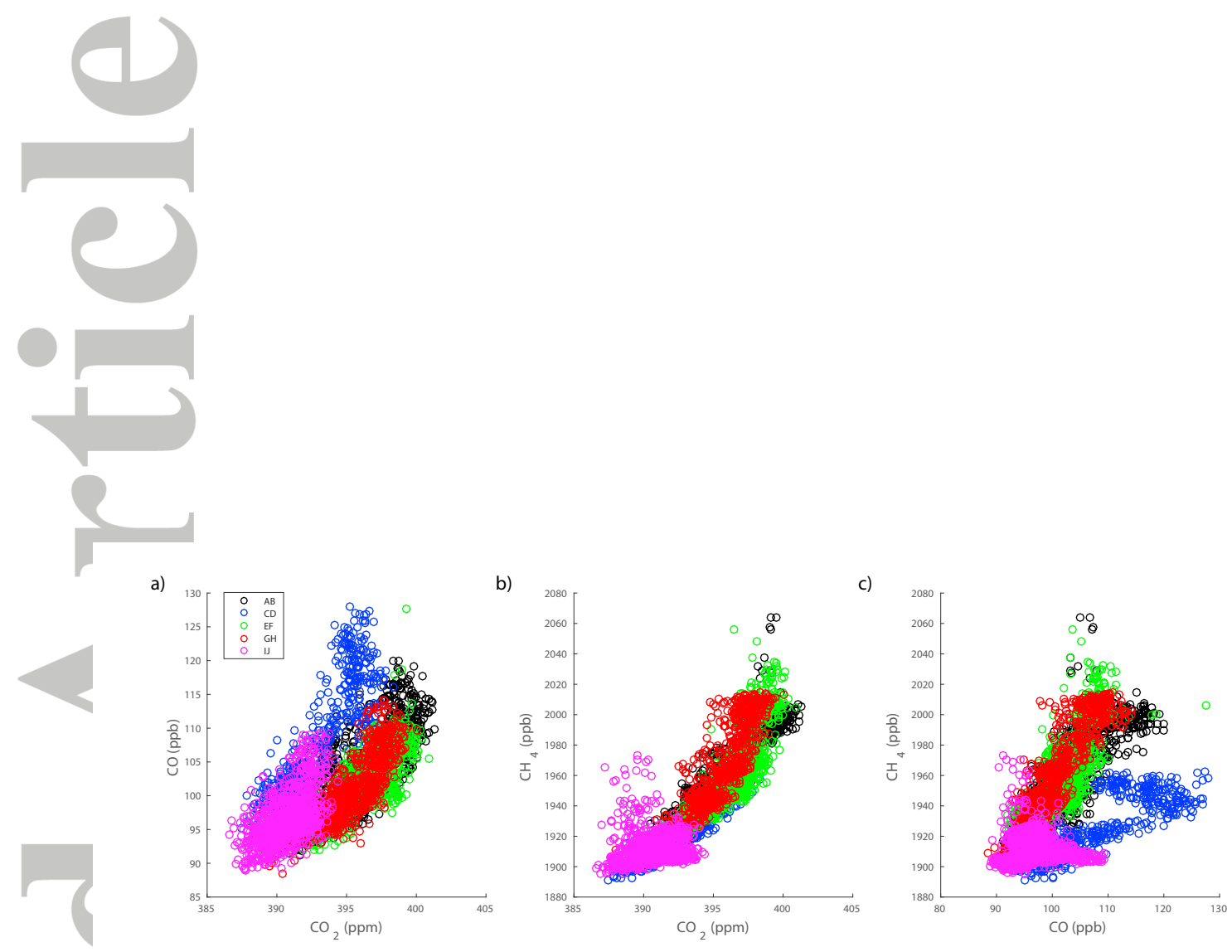

Figure 8. Scatter plots of (a) $\mathrm{CO}_{2}$ and $\mathrm{CO}$, (b) $\mathrm{CO}_{2}$ and $\mathrm{CH}_{4}$, and (c) $\mathrm{CO}$ and $\mathrm{CH}_{4}$ mole fractions from the aircraft transects. Each transect is represented with a different color.

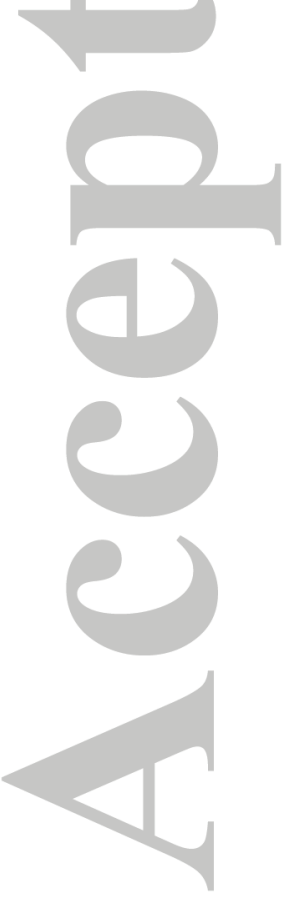

(C)2017 American Geophysical Union. All Rights Reserved. 